University of Rhode Island

DigitalCommons@URI

Open Access Master's Theses

1972

\title{
Solubility of Four Aminobenzoate Esters in Water and Normal Alcohols at Several Temperatures
}

Peter Allen Schwartz

University of Rhode Island

Follow this and additional works at: https://digitalcommons.uri.edu/theses

\section{Recommended Citation}

Schwartz, Peter Allen, "Solubility of Four Aminobenzoate Esters in Water and Normal Alcohols at Several Temperatures" (1972). Open Access Master's Theses. Paper 224.

https://digitalcommons.uri.edu/theses/224

This Thesis is brought to you for free and open access by DigitalCommons@URI. It has been accepted for inclusion in Open Access Master's Theses by an authorized administrator of DigitalCommons@URI. For more information, please contact digitalcommons-group@uri.edu. 


\section{SOLUBILITY OF FOUR AMINOBENZOATE ESTERS IN WATER AND NORMAL ALCOHOLS \\ AT SEVERAL TEMPERATURES}

BY PETER ALLEN SCHWARTZ

A DISSERTATION SUBMITTED IN PARTIAL FULFILLMENT OF THE REQUIREMENTS FOR THE DEGREE OF MASTER OF SCIENCE IN PHARMACY 


\section{MASTER OF SCIENCE THESIS \\ OF}

PETER ALLEN SCHWARTZ

\section{Approved:}

Thesis Committee:

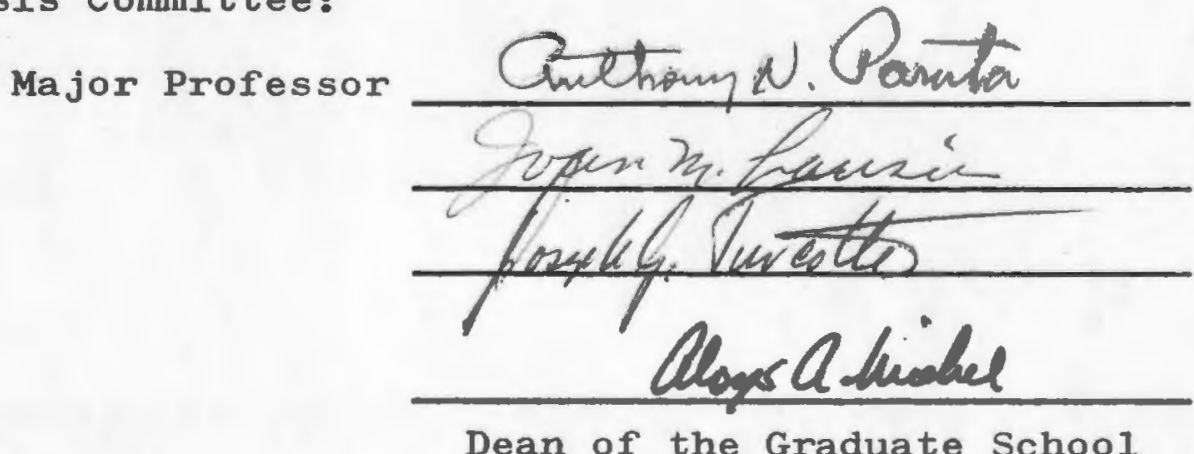

$$
\text { UNIVERSITY OF RHODE ISLAND }
$$




\section{ACKNOWLEDGMENT}

Acknowledgment is gratefully made to the faculty members of the Department of Pharmacy of the University of Rhode Island for their suggestions and criticisms. Special thanks are extended to Doctor George E. Osborne for his advice on exacting literary style, to Doctor Anthony N. Paruta for his guidance and supervision, and to my wife, Sheila, who sweated this one out with me. 


\begin{abstract}
Equilibrium solubilities of the first four homologous
\end{abstract} alkyl p-aminobenzoate esters were determined in methanol, ethanol, n-propanol and water at $25^{\circ}, 33^{\circ}$, and $40^{\circ} \mathrm{C} . ;$ the esters and the alcohols comprise separate but similar homologous series. The solution process of a solute may be considered to be the summation of two sequential steps, melting and mixing, and the magnitude of solubility depends upon temperature and the extent of interactions between solute and solvent molecules.

Quantitative solute concentrations, obtained from spectrophotometric analysis, were converted by computer to mole fractions. Statistical analyșis of the logarithmic mole fraction solubilities of the aminobenzoates, which were linear with respect to both reciprocal absolute temperature and the logarithim of absolute temperature generated enthalpies and entropies of solution, respectively. The heats of fusion and the melting points of these aminobenzoates were determined in order to calculate their ideal solubilities. Partial molal free energies of each solution were calculated from the activity coefficients of the solutes, i.e., the comparison of ideal to actual solubility. Solubilities of the aminobenzoates are linear with increasing temperature, and directly related to the homologous 
nature of the esters, i.e., alkyl carbon number. However, these data proved to be of limited utility in the correlation between theoretical and actual solubilities with respect to the polarity differences between solute and solvent. 
TABLE OF CONTENTS

Page

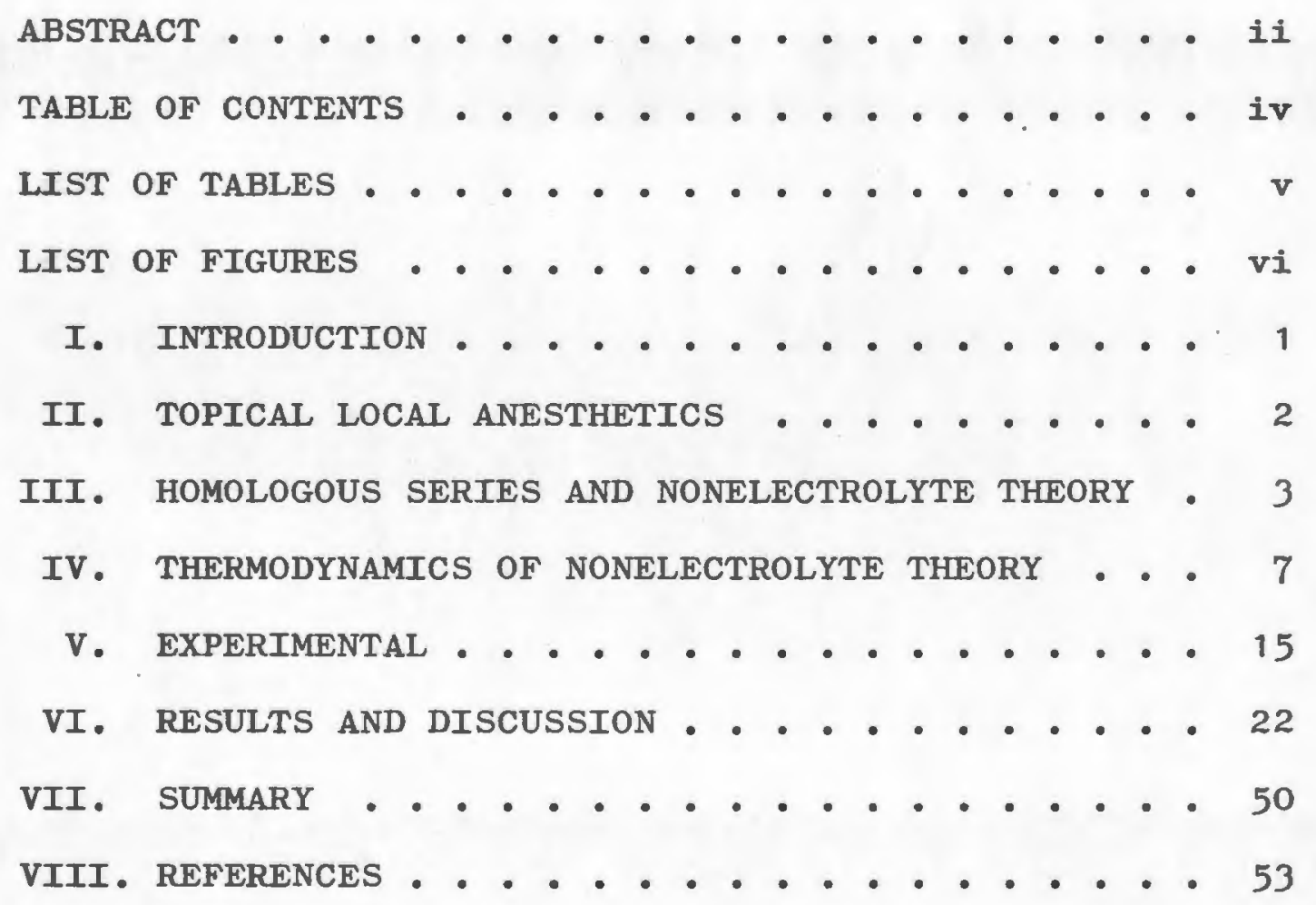




\section{LIST OF TABLES}

I. Structure and Thermal Properties

of the Alkyl p-Aminobenzoate Esters . . . . 23

II. Optical Properties and Modified

Beer's Parameters of Equation 20 for

Alkyl p-Aminobenzoate Esters . . . . . 24

III. Summary of the Average Mole Fraction

Solubilities of the Alkyl p-Aminobenzoate

Esters in each Solvent at $25^{\circ}, 33^{\circ}$, and $40^{\circ} \mathrm{C} .26$

IV. Thermodynamic Enthalpies and Entropies

of Solution... . . . . . . . . . 31

v. Dielectric Constants of the Alcohols at $25^{\circ}, 33^{\circ}$, and $40^{\circ} \mathrm{C}$. . . . . . . . . 36

VI. Activity Coefficients for the Alkyl

p-Aminobenzoates Based upon the Ideal

Solubilities from Equation 3.... . . 41

VII. Partial Molal Excess Free Energies Cal-

culated from the Activity Coefficients of

the Alkyl p-Aminobenzoates (Table VI) . . . 42 


\section{LIST OF FIGURES}

1. Melting Point of Aminobenzoate Esters

Versus the Alkyl Carbon Number . . . . . .

2. Natural Logarithm of Mole Fraction

Solubility of the Aminobenzoates in

Ethanol at $25^{\circ}, 33^{\circ}$, and $40^{\circ} \mathrm{C}$. Versus

the Alkyl Carbon Number . . . . . . . .

3. Natural Logarithm of Mole Fraction

Solubility of the Aminobenzoates in

Methanol at $25^{\circ}, 33^{\circ}$, and $40^{\circ} \mathrm{C}$. Versus

the Melting Point ........... 30

4. Natural Logarithm of Mole Fraction

Solubility of Methyl, Ethyl, Propyl, and

Butyl Aminobenzoate in Propanol Versus

the Reciprocal of the Absolute Temperature . 32

5. Natural Logarithm of Mole Fraction

Solubility of Methyl, Ethyl, Propyl, and

Butyl Aminobenzoate in Propanol Versus the

Natural Logarithm of the Absolute

Temperature . . . . . . . . . . . .

6. Natural Logarithm of Mole Fraction

Solubility of Methyl, Ethyl, Propy1, and

Butyl Aminobenzoate Versus the Dielectric

Constant of the Alcohol Solvents at $25^{\circ} \mathrm{C} . . .37$

7. Natural Logarithm of Mole Fraction

Solubility of Methyl, Ethyl, Propyl, and

Butyl Aminobenzoate Versus the Dielectric

Constant of the Alcohol Solvents at $33^{\circ} \mathrm{C}$. . 38

8. Natural Logarithm of Mole Fraction

Solubility of Methyl, Ethyl, Propyl, and

Butyl Aminobenzoate Versus the Dielectric

Constant of the Alcohol Solvents at $40^{\circ} \mathrm{C}$. . 39 
9. Natural Logarithm of Mole Fraction

Solubility of the Aminobenzoates in Water at $25^{\circ}, 33^{\circ}$, and $40^{\circ} \mathrm{C}$. Versus the Alkyl Carbon Number.

10. Natural Logarithm of Mole Fraction

Solubility of Methyl, Ethyl, Propyl, and

Butyl Aminobenzoates in Water Versus the

Reciprocal of the Absolute Temperature . . . 46

11. Natural Logarithm of Mole Fraction

Solubility of Methyl, Ethyl, Propyl, and

Butyl Aminobenzoates in Water Versus the

Natural Logarithm of the Absolute Temperature . 47 


\section{INTRODUCTION}

Solubility results principally from interactions between solute and solvent molecules (1). The extent of these interactions, i.e., the magnitude of solubility, depends partially upon the polarity and the hydrogen bonding characteristics of the solution components with respect to each other and to themselves; it depends also on the temperature of the system. The present work applies a multivarient approach to solubility data generated from a homologous series of solutes and solvents in an attempt to distinquish the effects of temperature, polarity and structure on the dissolution of nonelectrolytes.

Solutes studies included four normal alkyl p-aminobenzoate esters (methyl, ethyl, n-propyl, and n-butyl) chosen because these esters comprise a homologous series which differ in structure from each other by one methylene $\left(\mathrm{CH}_{2}\right)$ group. The solvents were water and the normal alcohols: methanol, ethanol, and n-propanol chosen as a similar homologous series that would provide a wide range of solvent polarity. The equilibrium solubilities of each solute in these solvents were determined at several temperatures to provide enthalpies and entropies of solution with respect to fundamental thermodynamic relationships. 
II. TOPICAL LOCAL ANESTHETICS

Topical anesthetics differ from local anesthetics primarily in that their solubility in water makes them unsuitable for injection (2). They cannot penetrate the intact skin (keratinized surface), but they are rapidly absorbed by mucosal surfaces (3). The toxicity of cocaine, introduced clinically in 1884 as an effective topical anesthetic $(2,3$, $4,5,6)$ led to a search for safer agents. The aminobenzoate esters were found to be nontoxic, nonirritating, and stable in solution; for these reasons they are frequently used for their anesthetic effect on mucous membrane tissue $(2,4,7)$.

Local anesthetic action is explained on the basis of a typical structural formula (5):

\section{LIPOPHILIC . . . . . INTERMEDIATE....... HYDROPHILIC \\ CENTER \\ CHAIN \\ CENTER}

The hydrophilic center, an amino group, is attracted to polar groups in the lipoprotein of the neural membrane (2) and binds to a receptor molecule, probably by donation of a hydrogen bond (8), while the nonpolar, lipophilic portion of the molecule attaches to the lipoid phase of the membrane (2). These chemical combinations stabilize the membrane potential and interfere with the generation and transmission of impulses along the nerve fibers $(2,3,6,8)$. 


\section{HOMOLOGOUS SERIES AND NONELECTROLYTE SOLUBILITY}

The solubility of nonelectrolytes has often been interpreted on the basis of polarity differences between solutes and solvents $(9,10,11,12,13,14,15)$. An incremental increase in the length of a hydrocarbon side chain effects a polarity difference between consecutive members of a homologous series. These structural differences result in altered physical properties such as boiling point elevation, increased partition coefficient (Iipid solubility), decreased aqueous solubility and increased surface tension $(4,7)$. Normally, physiologic activity of a homologous series increases with chain length $(4,7)$ and is inversely proportional to water solubility (16). The anesthetic action and toxicity of the alkyl p-aminobenzoates is greatest for the butyl ester, the least water soluble of the homologs $(4,7)$.

Since many properties of a homologous series change according to a geometric progression (16), the plot of the logarithm of these properties against the carbon number of the nonpolar hydrocarbon chain is linear. Solubility studies, carried out by Yalkowsky et al.(17), on the first four homologs of the alkyl p-aminobenzoate esters, demonstrated such linearity for semilogarithmic plots of solubility in silicone oil and hexane, two nonpolar solvents, as 
well as their partition coefficients with water against alkyl carbon numbers. Yalkowsky used the heats of fusion, melting points and solubility parameters to generate expected values for molar solubility all of which agreed well with the experimental values for the two nonpolar solvents. However, he found poor agreement with experimental data for water, a polar, hydrogen bonding solvent.

The similar series of homologous esters, alkyl phydroxyaminobenzoates, has been studied by Restaino and Martin (9), and Paruta (10) in several alcohols, i.e., polar, hydrogen bonding solvents. The Hildebrand and Scott solubility parameter theory (11) was used in these studies to predict the points of maximum solubility in each solvent. However, the magnitude of solubility depends upon specific solute-solvent interactions (12), and is not always predictable.

The solubility parameter, $\delta$, is a measure of intermolecular forces or cohesion between molecules and is defined as "the square root of the energy of vaporization per cubic centimeter of a liquid." (18) The relation is

$$
\delta=\left(\Delta E^{\text {vap }} / v\right)^{1 / 2}
$$

where $\Delta E^{\text {vap }}$ and $V$ are molal quantities, and the quotient, $\Delta \mathrm{H}^{\mathrm{vap}} / \mathrm{v}$ is called the energy of cohesion or the cohesive energy density (18). Highly polar substances have large solubility parameter values, and nonpolar solvents have low values. For example water has a very high value of 23.4 compared with 7.3 for nonpolar hexane (18). Paruta et al. (12) 
have shown that the solubility parameter is also a linear function of the dielectric constant, $\mathcal{E}$; so that

$$
\delta=0.2 \varepsilon+7.5
$$

and other investigators have used dielectrics rather than solubility parameters to characterize the polarity of solutes and solvents $(9,10,12,13,14)$.

Chertkoff and Martin (13) used binary mixtures of several polar soḷents to provide a range of dielectric constants that included that of benzoic acid. Solubility studies with these binary mixtures and benzoic acid demonstrated solubility maxima in that solvent blend which had a dielectric constant closest in value to that of benzoic acid. Thus when the polarities of the solvent blend and the solute are alike, or nearly alike, it is presumed that the solute and solvent blend exert the same forces on each other. At this point of negligible polarity difference between solute and solvent, the dielectric constant of the solvent blend approximates that of the solute and is defined as the dielectric requirement of the solute (12).

Gorman and Hall (14) used similar binary mixtures of polar solvents with several solutes and showed linear relationships between the logarithm of the mole fraction solubility and the dielectric constants of the solvent blends. However these studies showed that the magnitude of maximum solubility of the same solute in different solvent blends was not predictable and indicates that solute solubility varies with the nature of the solvent system employed as 
well as with the dielectric constant of the solvent system. Paruta (19) explained that apparent differences in solubility maxima in blended solvent systems were the consequence of different solubility expressions, i.e., mg. per m1., mg. per gram. or mole fraction, used by experimenters. More importantly, some solutes exhibit several solubility maxima in blended solvent systems, a result which differs significantly from the Hildebrand and Scott theory (11) which predicts a single peak solubility.

Although the Hildebrand theory is quantitatively limiting for molecules of different polarities, it adequately predicts qualitative or relative solubility, i.e., when the molecules are "sufficiently alike so that they are under the same forces in the mixture as in the pure liquids" (20), and provides a suitable model for comparing the nonideal behavior of nonelectrolytes in polar solvents. 


\section{THERMODYNAMICS OF NONELECTROLYTE SOLUBILITY}

When two solutions of similar physical properties are mixed and there is no evolution or absorption of heat, the resulting solution is termed "ideal" or "perfect" $(21,22)$ and can be used as a reference state (23). Although the majority of drug molecules are nonelectolytes, most pharmaceutical solvents are either polar or semipolar with strong specific interactions, such as association, solvation or hydrogen bonding, and these solutions are nonideal. Interpretation of this nonideal solubility behavior is made in terms of the fundamental thermodynamic functions of enthalpy, entropy, and free energy (24); structural differences (25); activity coefficients (26); and solute-solvent interactions (27)

Solubility is a colligative property, and is closely related to the temperature dependent thermodynamic equation for freezing point depression $(22,28)$. At any temperature the concentration of pure solid solute is constant and is in equilibrium with the liquid state. The solution process is considered by Mahan (22) to occur in two steps:

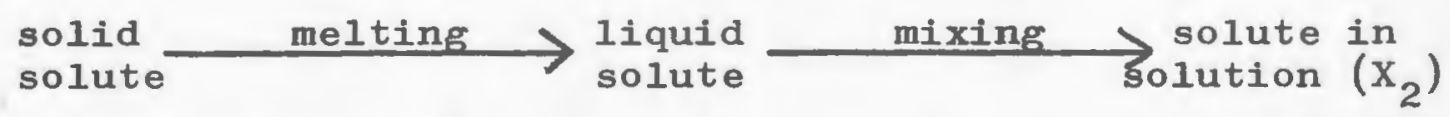
where $x_{2}$ is the solute mole fraction. In binary solutions, it is customary "to use subscript 1 to represent the solvent, 
the substance in which the solute, represented by subscript 2, dissolves." (23) The enthalpy change for melting is the heat of fusion, $\Delta H^{F}$, and the enthalpy for the second step is the heat of mixing (22). For ideal solutions the enthalpy of the second step is zero, since by definition no heat is evoled or absorbed (29).

The equation for the ideal mole fraction solubility (28) of a solute, $x_{2}{ }^{i}$, at a temperature below its melting point, $T_{m}$, is given in terms of the natural logarithm of the solubility, i.e.,

$$
1_{n} x_{2}^{i}=-\Delta H^{F}\left(\frac{1}{T}-\frac{1}{T_{m}}\right)
$$

assuming that the heat of fusion is constant with respect to temperature and that the gas constant, $R$, equals $1.987 \mathrm{cal} / /$ degree. The solubility at any given temperature should be the same for all solvents with which it forms an ideal solution (28). From Equation 3, it is apparent that a solute with a low heat of fusion and a low melting point will have a high ideal solubility (28), that solubility of a solute increases as the melting point decreases (31), and that solubility appears to be independent of the nature of the solvent.

Hildebrand and Scott have equated the activity of a solute, $a_{2}$, with $x_{2}^{i}$ for ideal solutions (32). The activity is a relative quantity and represents the deviation from a designated reference state (23). The most useful standard state for solubility is one in which the pure liquid solute, 
extrapolated below the melting point as a supercooled liquid (33), has a value of unity when its mole fraction is unity. The ratio of the activity to the mole fraction, is the activity coefficient, $\gamma, i . e$.

$$
\gamma=a / x
$$

Because the activity varies with composition, the activity coefficients, which remain relatively constant, are more suitable parameters for expressing deviations from ideal solutions (23).

Equation 3 is valid only when the heat of fusion is constant with respect to temperature (28). From heat of fusion at the melting point, $\Delta H_{m}{ }^{F}$, and the change in molal heat capacity between liquid and solid solute, $\Delta C_{p}$, also extrapolated below the melting point (18), the heat of fusion at any temperature can be derived (34):

$$
\Delta H^{F}=\Delta H_{m}^{F}-\Delta C_{p}\left(T_{m}-T\right)
$$

Substitution of this heat expression in Equation 3 gives the following for ideal mole fraction solubility

$$
\text { 1n } \begin{aligned}
x_{2}{ }^{i}= & -\left[\Delta H_{m}{ }^{F} / R\left(T_{m}-T / T_{m} T\right)\right]+\left[\Delta C_{p} / R\left(T_{m}-T / T\right)\right] \\
& -\left[\Delta C_{p} / R\left(\ln T_{m} / T\right)\right]
\end{aligned}
$$

For the ideal solution the plot of the natural $10 \mathrm{~g}$ of the mole fraction solubility, in $x_{2}$, versus the reciprocal of the absolute temperature, $1 / T$, has a slope proportional to the heat of fusion at the melting point and an intercept proportional to the entropy of fusion, i.e., $\Delta H_{m}{ }^{F} / T_{m}$. Data from nonideal solutions plotted in this manner have slopes 
and intercepts proportional to the differential heats and entropy of solution respectively. (20)

Hildebrand and scott have shown that the heat capacity is not negligible and can be approximated by the entropy of fusion (35). Substitution of $\Delta s_{m}^{F}$ for $\Delta c_{p}$ in Equation 6 cancels out the first two terms on the right side and leaves the ideal mole fraction solubility equation as

$$
\text { in } x_{2}^{i}=\left(\Delta S_{m}^{F} / R\right)\left(1 n T / T_{m}\right)
$$

Accordingly, a plot of $1 \mathrm{n} \mathrm{x}_{2}$ versus the natural $10 \mathrm{~g}$ of the absolute temperature, in $T$, is linear with a slope proportional to the entropy of fusion. For nonideal data the entropy of solution can be obtained from the slope of this line $(20,36)$.

According to Hildebrand some nonideal solutions can be classed as regular solutions, i.e., "a regular solution is one involving no entropy change when a small amount of one of its components is transferred to it from an ideal solution of the same composition, the total volume remaining unchanged." (37) Since orienting and chemical effects, such as hydrogen bonding, solvation or association (37), are absent in regular solutions (38), and molecules are randomly distributed as in ideal solutions, the two types of solutions have equal entropies (37). The deviation from ideality for a regular solution represents the magnitude of the enthalpy of mixing, since there is no heat evolved in the formation of an ideal solution (23). 
Raoult's law, the linear relationship between partial pressure of a solvent and its mole fraction in an ideal solution $(23,39)$ has also been used as a reference state for consideration of nonideality. Negative deviations from Raoult's law are due to hydrogen bonding between polar compounds and result in an increased solubility (40). The cohesive (attraction) forces of the solid solute molecules (41) account for positive deviations and produce a smaller solubility than in an ideal solution. This corresponds to a positive heat (energy) mixing and an increase in volume upon mixing (43).

The free energy, F, "represents the maximum of work which can be obtained from a given process and applied to useful purposes." (44) At equilibrium the total free energy is at a minimum (45) with no separation of enthalpic and entropic components (46). Nonideal solutions have an excess free energy of mixing which can be regarded as "the excess of the nonideal free energy of mixing over the ideal free energy of mixing" (47), i.e., in terms of free energies (48)

$$
F^{E}=F_{\operatorname{mix}}-\left(F_{\operatorname{mix}}\right)_{i d e a 1}
$$

The free energy of mixing is given by Hildebrand and Scott (49) as

$$
\mathrm{F}_{\text {mix }}=\operatorname{RT}\left(\mathrm{x}_{1} \ln \mathrm{a}_{1}+\mathrm{x}_{2} \ln \mathrm{a}_{2}\right)
$$

while the free energy for the formation of an ideal solution of the same composition $(23,50)$ is obtained from 
Scatchard as

$$
\left(F_{\operatorname{mix}}\right)_{\text {ideal }}=\operatorname{RT} \sum_{X} \ln X=R T\left(X_{1} \ln X_{1}+X_{2} \ln X_{2}\right) \quad[10]
$$

Since there is no entropy change for regular solutions, the excess entropy is zero and the excess free energy of mixing equals the excess enthalpy (23).

Taking the natural $\log$ of the activity coefficient in Equation 4 and rearranging gives the natural log mole fraction

$$
\ln x_{2}=\ln a_{2}-\ln \gamma_{2}=\ln x_{2}{ }^{i}-\ln \gamma_{2}
$$

The total excess free energy is the difference between Equations 9 and 10, using the activity coefficient equation above

$$
F^{E}=\operatorname{RT}\left(x_{1} \ln \gamma_{1}+x_{2} \ln \gamma_{2}\right)
$$

from which the partial molal excess free energy for the solute can be derived as

$$
\overline{\mathbf{F}}^{\mathrm{E}}=\mathrm{Rt} \ln \gamma_{2}
$$

A partial molal quantity is defined as "the rate of increase in the content of the system in that particular quantity while the component is being added to the system." (51) However, Hildebrand warns that the physical property of partial molal quantities cannot be attributed to "the molecules of one species alone," and that it is "really a property of the solution as a whole, not a property of the component in question." (52)

When the activity coefficient is greater than unity, the excess free energy in Equation 13 is positive and is 
referred to as a positive deviation from Raoult's law of the ideal solution, and a negative value as a negative deviation (47). The $\log \gamma_{2}$ term for the excess free energy of regular solutions is due to the intermolecular forces of the solute and solvent that are not present in ideal solutions. These forces can be characterized by considering the solubility parameters of the solute and solvent, the volume fraction of the solvent, $\phi_{1}$, and the molar volume of the solute, $v_{2}$, so that the deviation from ideal is (53)

$$
\ln \gamma_{2}=\left(\phi_{1}-\phi_{2}\right)^{2} \mathrm{v}_{2} \phi_{1}^{2} / \mathrm{RT}
$$

If the ideal mole fraction (Equation 6) and the activity coefficient defined above are substituted in Equation 11, the mole fraction solubility equation of Hildebrand and Scott $(54)$ is obtained

$$
\begin{aligned}
\text { 1n } x_{2}= & \left.f \Delta H_{m}{ }^{F} / R\left(T_{m}-T\right) / T_{m} T\right]+\left[\Delta C_{p} / R\left(T_{m}-T / T\right)\right] \\
& -\left[\Delta C_{p} / R\left(1 n T_{m} / T\right)\right]-\left[\left(\phi_{1}-\phi_{2}\right)^{2} V_{2} \phi_{1}{ }^{2} / R T\right]
\end{aligned}
$$

The heat capacity terms in this equation have been neglected by many investigators who were unable to measure them or who considered them negligible (17) and this equation can be reduced to one which is quite similar to Equation 3

$$
\text { 1n } \mathrm{X}_{2}=\left[-\Delta_{\mathrm{H}}{ }_{\mathrm{m}}^{\mathrm{F}} / \mathrm{R}\left(1 / \mathrm{T}-1 / \mathrm{T}_{\mathrm{m}}\right)\right]-\left[\left(\phi_{1}-\phi_{2}\right)^{2} \mathrm{v}_{2} \phi_{1}{ }^{2} / \mathrm{RT}\right] \quad[16]
$$

Since the solubility parameter is a measure of polarity, the greater the difference in polarity between solute and solvent, the greater the deviational term of the activity coefficient. 
Entropy is related to structure (20) and indicates the probability of a combination between solute and solvent (56). Increased entropy of solution denotes a more probable state for such a system than do the separate pure solute and solvent (37). As the degree of randomness and disorder for a system increases, the entropy increases, but the free energy decreases (57). For example, at increased temperatures there is more randomness, i.e., increased entropy, while the amount of useful work or free energy is diminished. For alcohols in solution with nonpolar components there is a decreased entropy due to specific interactions, i.e., ordering due to hydrogen bonding, and large positive deviations from ideality are expected (58). Highly nonideal solubility with such large entropy terms cannot be calculated from any of the equations above and are best calculated in terms of free energies (38) which avoids serious errors of oversimplification, and does not separate enthalpic and entropic effects (46). 


\section{v. EXPERTMENTAL}

\section{Materials:}

Equipment - Items used included:

Thomas-Hoover Capillary Melting Point Apparatus \#64041

Cary Model 16 Spectrophotometer ${ }^{2}$

Prescision Porta-Temp Unit ${ }^{3}$

Mettler Balance, Type H6r $\mathrm{T}^{4}$

Rotating Sample Holder with small motor 5

Pyrex Corning Glass Woo ${ }^{6}$

Cahn Gram Electrobalance Model $1 \mathrm{~B}^{7}$

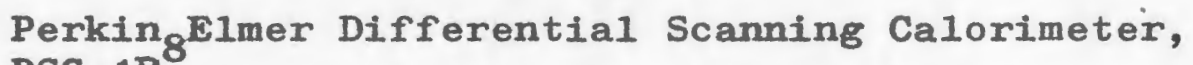
DSC -18

Xerox Copier Model $660-1^{9}$

1. A. H. Thomas Company, Philadelphia, Pa.

2. Cary Instruments, Monrovia, Calif.

3. Prescision Scientific Company, Chicago, I11.

4. Mettler Instrument Corporation, Princeton, N. J.

5. U.R.I. Department of Pharmacy

6. Coming Glass Works, Corning, N. Y.

7. Cahn Instruments, Paramount, Calif.

8. Perkin Elmer Corporation, Instrument Division, Norwalk, Conn.

9. XeroX Corporation, Rochester, N.Y. 
10 gallon glass aquarium ${ }^{10}$

IBM Computer Mode1 360-50 $0^{11}$

\section{Chemicals:}

methyl p-aminobenzoate, lot $3403^{12}$

ethy1 p-aminobenzoate, lot Ex $305^{13}$

n-propy1 p-aminobenzoate, lot $3^{14}$

n-butyl p-aminobenzoate, lot $7^{15}$

n-buty1 p-aminobenzoate, lot A-7886 ${ }^{16}$

methyl alcohol, anhydrous, spectrophotometric grade solvent, lot VMN 17

absolute ethyl alcohol, USP-NF, reagent quality ${ }^{18}$

1-propano1, "Baker Analyzed" reagent, lot $39420^{19}$

ethyl alcohol 95\%, USP grade, lot TN $288671^{20}$

10. Eastern Scientific Company, Providence, R.I.

11. International Business Machines, White Plains, N.Y.

12. Eastman Chemical Company, Rochester, N.Y.

13. Matheson, Coleman and Be1l, Norwood, Ohio.

14. City Chemical Company, N.Y., supplied through the courtesy of Astra Pharmaceutical Products, Inc., Worcester, Md.

15. Matheson, Coleman and Bell, Norwood, Ohio.

16. Abbott Laboratories, N. Chicago (supplied through the courtesy of Abbott Labs).

17. Mallinckrodt Chemical Works, St. Louis, Mo.

18. U. S. Industrial Chemicals Company, New York, N.Y.

19. J. T. Baker Chemical Company, Phillipsburg, N.J.

20. Industrial Chemicals Co., Littleton, Me. 
stearic acid, $99.8 \%$ pure $^{21}$

water, distilled and deionized 22

\section{Calibration of the Calorimeter}

The calorimeter cell of a differential scanning calorimeter, DSC, used to determine heats of fusion, was calibrated with stearic acid, 99.8 per cent pure. Three samples of the acid, in amounts empirically chosen to produce endothermic fusion peaks of maximum area, were accurately weighed $( \pm 0.002 \mathrm{mg}$.$) on an electrobalance into$ tared aluminum pans that were subsequently sealed to prevent volatilization. The samples were heated in a nitrogen atmosphere in the calorimeter cell over a temperature range of 60 to $75^{\circ} \mathrm{c}$. , at a heating rate of $5 \%$ min., and at a chart recording speed of $120 \mathrm{in./min}$. Each sample was melted twice, and calibration constants were calculated from only those curves having essentially straight baselines for both pre- and postfusion.

The value of $\triangle \mathrm{H}_{\mathrm{m}} \mathrm{F}$, the heat absorbed by a sample during fusion, is proportional to the area under the curve defined by the endothermic peak and by a line drawn between the point of departure from the baseline (onset of fusion), to the point of baseline return after fusion (59). The thermograms generated by the samples were reproduced on paper of

21. Applied Sciences, State College, Pa.

22. U.R.I. Fogarty Building 
a uniform thickness, and each of these areas was carefully cut out and weighed $(60)$. The stearic acid calibration coefficient, 0.0641969 , is the average of the determinations from each sample calculated according to the following equation:

$$
K=\frac{H_{\mathbf{s a}}{ }^{\mathrm{F}} \mathrm{M}}{\mathrm{W}}
$$

where $K=$ calibration coefficient, mcal./mg. of paper,

$\mathrm{H}_{\mathrm{sa}} \mathbf{F}=$ heat of fusion for stearic acid, $-47.54 \mathrm{mcal} . / \mathrm{mg}$,

$M=$ weight of stearic acid sample, mg.,

$W=$ weight of stearic acid sample, $\mathrm{mg}$. of paper,

$r=$ power coefficient of the instrument.

Because the instrument does not provide readings in

Celsius degrees, the fusion endotherms of stearic acid were.

used to determine a calibration constant for temperature

correction. The melting point for a solid is best represented by the extrapolation to the prefusion baseline of its endotherm (61). The known melting point of $68.82^{\circ} \mathrm{C}$. was subtracted from the average value of the instrument readings for the onset of fusion for stearic acid to produce a correction constant of $378.4^{\circ} \mathrm{C}$. (62).

\section{Melting Point Determinations}

The average of the two calorimeter melting points for each aminobenzoate ester was converted to Celsius melting points by subtracting the temperature correction constant. Since there was a close agreement in melting points between 
experimental and literature values for the esters, these compounds were used directly and without further purification.

\section{Heats of Fusion}

Samples of the four aminobenzoate esters were carefully weighed into aluminum volatile sample pans, and thermograms of a 10 degree prefusion baseline and a fusion endotherm were recorded. Because direct renelts of the same sample indicated an apparent formation of liquid crystals after fusion, each fused sample was cooled to $0^{\circ} \mathrm{C}$. for 30 minutes prior to remelting. Recordings were analyzed for melting points and endothermic areas in the same manner as for stearic acid, and heats of fusion were calculated using the following formula:

$$
\mathrm{H}_{\mathrm{m}} \mathrm{F}=\frac{\mathrm{Kr} \mathrm{W}_{\mathrm{s}}}{\mathrm{M}_{\mathrm{s}}}
$$

where $K$ and $r$ are the same as before, and

$$
\begin{aligned}
& H_{m} F=\text { heat of fusion at the melting point, mcal./mg., } \\
& W_{s}=\text { weight of sample area, mg. of paper } \\
& M_{S}=\text { weight of sample, mg. }
\end{aligned}
$$

\section{Solubility Determinations}

The solubility of the four aminobenzoate esters in several alcohols and water was determined by the following procedure (63). Each solute in an amount in excess of its solubility was placed in teflon-lined screw cap glass vials with each solvent. The vials were sealed with adhesive 
tape. Vials were rotated at 28 RPM in a large constant temperature $\left( \pm 0.2^{\circ} \mathrm{C}.\right)$ water bath maintained successively at 25,33 , and $40^{\circ} \mathrm{C}$.

After an equilibrium solubility was attained by at least 24 hours of continuous rotation ${ }^{1}$, each of $\operatorname{six}^{2}$ sample vials was removed in succession for assay. The exterior of the vial was quickly dried, the sealing tape removed, and the cap carefully unscrewed to prevent water contamination. A filtered aliquot of the saturated solution was pipetted into tared containers, weighed, and appropriately diluted for spectrophometric assay with 95 per cent ethanol to give a final concentration of solute in the range of 1 to 15 micrograms per milliliter. All pipettes were prewarmed to prevent thermal precipitation, and each had a pledget of fiber glass wrapped around its tip to act as a filter.

\section{Spectrophotometric Determination}

The spectrophotometer was calibrated for each aminobenzoate ester at its wavelength of maximum absorbance, at concentrations up to 15 micrograms per milliliter in 95 per cent ethanol, and in matched silica cells. A least squares method (64) was used to determine the statistical significance (alpha $=0.0001$ ) of the linear relationship between

1. Previous studies showed that this time was sufficient to obtain saturated solutions at $25^{\circ} \mathrm{C}$.

2. Only 3 samples of propyl p-aminobenzoate were used because of its scarcity. 
absorbance and concentration, $1 . e .$, the Beer's law equation (65)

$$
A=a b c+B
$$

where $A$ = absorbance,

$a$ = absorptivity

b = sample path length, cm.

$c=$ concentration, grams/1iter

$B=a$ constant, usually very close to zero.

However, Lewis (66) states that "it is important to distinquish between the independent and the dependent variable according to the way in which the equation finally will be used." Therefore, a predictive equation of concentration as the function of absorbance is more desirable with respect to the significance of the least squares method. Since $A-B=a b c$, and $c=A / a b-B / a b$, equation 19 can be transformed to: $c=\mathbf{k A}-\mathbf{B}^{\mathbf{1}}$

\section{Calculations}

A computer program was written to utilize the modified Beer's parameters and compute the concentration of the. solute from the absorbance readings. The moles of solvent were determined by the difference from the weight of sample, and the mole fractions were calculated individually and averaged for the group of samples. Several other computer programs were used which calculated the ideal mole fractions, total and excess free energies. 


\section{RESULTS AND DISCUSSION}

The chemical structures of the alkyl p-aminobenzoate esters and their thermal properties are shown in Table' I. Experimentally determined DSC and capillary tube melting points in Table I agree well with literature values shown there, and are the same as those recently reported by Yalkowsky (17). The heats of fusion show the same trend as do the Yalkowsky data, i.e., enthalpies for the methyl and butyl esters are higher than for the ethyl and propyl esters.

Table II lists (1) the maximum absorbiog wavelengths, (2) the absorptivities (where the molar absorptivity (67) is the product of the absorptivity and the molecular weight of the ester), (3) the slope, $\mathbf{k}$, and (4) the intercept, $B^{\prime}$; both $k$ and $B^{\prime}$ were derived from Equation 20 for each ester. Because the hydrogen lamp of the spectrophotometer had to be replaced on several occasions, there are two sets of parameters listed for each ester. The molar absorptivities in ethanol are nearly the same for each of the four esters, while the other parameters show changes from one member to the next. The absorbing wavelengths and the absorptivities for the esters agree well with those reported in the literature (68). 
TABLE I

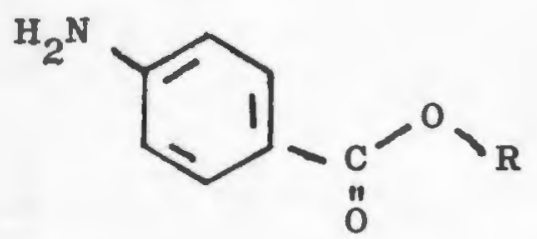

STRUCTURE AND THERMAL PROPERTIES OF THE ALKYL p-AMINOBENZOATE ESTERS

\begin{tabular}{|c|c|c|c|c|c|c|}
\hline \multirow[t]{2}{*}{ ESTER $^{a}$} & \multirow{2}{*}{$\begin{array}{c}\mathrm{R} \\
\text { substitutions }\end{array}$} & \multicolumn{3}{|c|}{ MELTING POINTS ${ }^{\circ} \mathrm{C}$. } & \multirow{2}{*}{$\begin{array}{l}\text { HEATS OF } \\
\text { FUSION } \\
\text { cal./mole }\end{array}$} & \multirow{2}{*}{$\begin{array}{l}\text { ENTROPY OF } \\
\text { FUSION } \\
\mathrm{cal} / \mathrm{mol} \mathrm{e}^{\circ}\end{array}$} \\
\hline & & Literature & $\begin{array}{c}\text { Capillary } \\
\text { Tube }\end{array}$ & DSC & & \\
\hline Methyl & $-\mathrm{CH}_{3}$ & $112^{b}, 114^{c}$ & $110.5-111$ & 112.5 & 5180 & $13 \cdot 5$ \\
\hline Ethy1 & $-\mathrm{CH}_{2} \mathrm{CH}_{3}$ & $89^{d}, 90^{c}, 92^{b}$ & $88-90$ & 89.7 . & 5030 & 13.9 \\
\hline n-Propy 1 & $-\mathrm{CH}_{2} \mathrm{CH}_{2} \mathrm{CH}_{3}$ & $73^{d}, 73-4^{b}, 75^{c}$ & $73-74$ & 73.0 & 5000 & $14 \cdot 5$ \\
\hline n-Buty1 & $-\mathrm{CH}_{2} \mathrm{CH}_{2} \mathrm{CH}_{2} \mathrm{CH}_{3}$ & $57^{\mathrm{d}}, 58^{\mathrm{b}, \mathrm{c}}$ & $56-58$ & 55.8 & 5290 & 16.1 \\
\hline
\end{tabular}

a. C. O. Wilson, 0. Gisvold, and R. F. Doerge, Textbook of Organic Medicinal and Pharmaceutical Chemistry, 5th ed., J. B. Lippincott Co., Philadelphia, 1966 , p. 602 .

b. Dictionary of Organic Compounds, Oxford University Press, 4th revision, New York, 1955

c. C. Weast, Handbook of Chemistry and Physics, 51 st ed., Chemical Rubber Company,

Cleveland, 1970.

d. R. Adams, et al, J. Amer. Chem. Soc., 48, 1758 (1926). 
TABLE II

OPTICAL PROPERTIES AND MODIFIED BEER'S PARAMETERS OF EQUATION 20 FOR ALKYL p-AMINOBENZOATE ESTERS

\begin{tabular}{|c|c|c|c|c|c|}
\hline $\begin{array}{l}\text { AMINOBENZOATE } \\
\text { ESTERS } \\
\text { (in } 95 \% \text { ethanoI) }\end{array}$ & $\begin{array}{l}\text { MAXIMUM } \\
\text { ABSORBING } \\
\text { WAVELENGTH } \\
\text { (nanometers) }\end{array}$ & ABSORPTIVITY & $\begin{array}{l}\text { MOLAR } \\
\text { ABSORPTIVITY } \\
\mathbf{x}\left(10^{4}\right)\end{array}$ & $\stackrel{k}{(m c g \cdot / m 1 .)}$ & $\begin{array}{l}\mathrm{B}^{\prime} \\
(\mathrm{mcg} \cdot / \mathrm{ml} .)\end{array}$ \\
\hline methy 1 & 295 & $\begin{array}{l}131.2 \\
139.5\end{array}$ & $\begin{array}{l}1.98 \\
2.11\end{array}$ & $\begin{array}{l}7.62 \\
7.17\end{array}$ & $\begin{array}{l}0.13 \\
0.14\end{array}$ \\
\hline ethy 1 & 294 & $\begin{array}{l}124.5 \\
123.9\end{array}$ & $\begin{array}{l}2.06 \\
2.05\end{array}$ & $\begin{array}{l}8.03 \\
8.07\end{array}$ & $\begin{array}{l}0.12 \\
0.12\end{array}$ \\
\hline n-propy 1 & 295 & $\begin{array}{l}116.4 \\
113.2\end{array}$ & $\begin{array}{l}2.09 \\
2.03\end{array}$ & $\begin{array}{l}8.59 \\
8.87\end{array}$ & $\begin{array}{l}0.12 \\
0.11\end{array}$ \\
\hline n-buty 1 & 294 & $\begin{array}{l}106.0 \\
108.7\end{array}$ & $\begin{array}{l}2.05 \\
2.10\end{array}$ & $\begin{array}{l}9.42 \\
9.19\end{array}$ & $\begin{array}{l}0.11 \\
0.11\end{array}$ \\
\hline
\end{tabular}


The average mole fraction solubilities of these esters in methanol, ethanol, n-propanol, and water, and the ideal solubilities predicted by both Equations 3 and 7 at $25^{\circ}, 33^{\circ}$, and $40^{\circ}$ are summarized in Table III and show an expected direct relationship between the magnitude of solubility and temperature for each solvent. Since the solute and the solvent molecules form separate but similar homologous series, solubility behavior is usually thought to be parallel with some physical parameters $(10,16)$. However, Lindstrom (24) has cautioned that such parallel interactions for a group of chemically related molecules, i.e., a simple homologous series, are not to be expected in all solvent systems because of polarity differences between molecules.

\section{Alkyl p-Aminobenzoate Solubility in the Normal Alcohols}

As seen in Table I, when the alkyl chain length increases, the melting point temperature decreases. Although this relationship is not strictly linear, a plot of the melting point temperature versus carbon number of the alkyl group (Figure 1) reflects a regularity in the structura1 difference between homologs. Figure 2, a plot of 1 n $x_{2}$ of the esters dissolved in ethanol against the carbon number of the alkyl group, shows a somewhat linear increase in solubility with increased chain length, and indicates that the difference in partial molal free energy between the solid solute and its saturated solution is constant for each successive homolog (16). Since the graph of the be- 
TABLE JII

SUMMARY OF THE AVERAGE MOLE FRACTION SOLUBILITIES OF THE ALKYL P-AMINOBENZOATE ESTERS IN EACH SOLVENT AT $25^{\circ}, 33^{\circ}, \mathrm{AND}^{\circ} 40^{\circ} \mathrm{C}$.

\begin{tabular}{|c|c|c|c|c|c|c|c|}
\hline \multirow{2}{*}{ SOLUTE } & \multirow{2}{*}{$\begin{array}{c}\text { TEMPERATURE } \\
{ }^{\circ} \mathrm{C} .\end{array}$} & \multicolumn{4}{|c|}{ SOLVENTS } & \multirow[t]{2}{*}{ IDEAL $\mathbf{A}^{\mathbf{a}}$} & \multirow[t]{2}{*}{ IDEAL $\mathbf{B}^{\mathbf{b}}$} \\
\hline & & WATER & METHANOL & ETHANOL & n-PKOPANOL & & \\
\hline \multirow[t]{3}{*}{ Methyl } & 25 & .000193 & .0367 & .0419 & .0306 & .1369 & .1752 \\
\hline & 33 & .000232 & .0524 & .0545 & .0428 & .1722 & .2096 \\
\hline & 40 & .000332 & .0730 & .0740 & .0586 & .2084 & .2442 \\
\hline \multirow[t]{3}{*}{$\overline{\text { Ethy1 }}$} & 2.5 & .000112 & .0945 & .0895 & .0836 & .2195 & .2539 \\
\hline & 33 & .000147 & .1256 & .1276 & .0953 & .2741 & .3054 \\
\hline & 40 & .000186 & .1811 & .1843 & .1455 & .3299 & .3576 \\
\hline \multirow[t]{3}{*}{ Propy 1} & 25 & .000064 & .1709 & .1634 & .1826 & .3100 & .3376 \\
\hline & 33 & .000076 & .2402 & .2177 & .2485 & .3866 & .4093 \\
\hline & 40 & .000094 & .4016 & .4018 & .3680 & .4648 & .4825 \\
\hline \multirow[t]{3}{*}{ Butyl } & 25 & .000015 & .2779 & .2212 & .2544 & .4319 & .4507 \\
\hline & 33 & .000025 & .5247 & .4319 & .3705 & .5457 & .5586 \\
\hline & 40 & .000040 & .7030 & .6220 & .6205 & .6632 & .6709 \\
\hline
\end{tabular}

a. calculated from Equation 3

b. calculated from Equation 7 


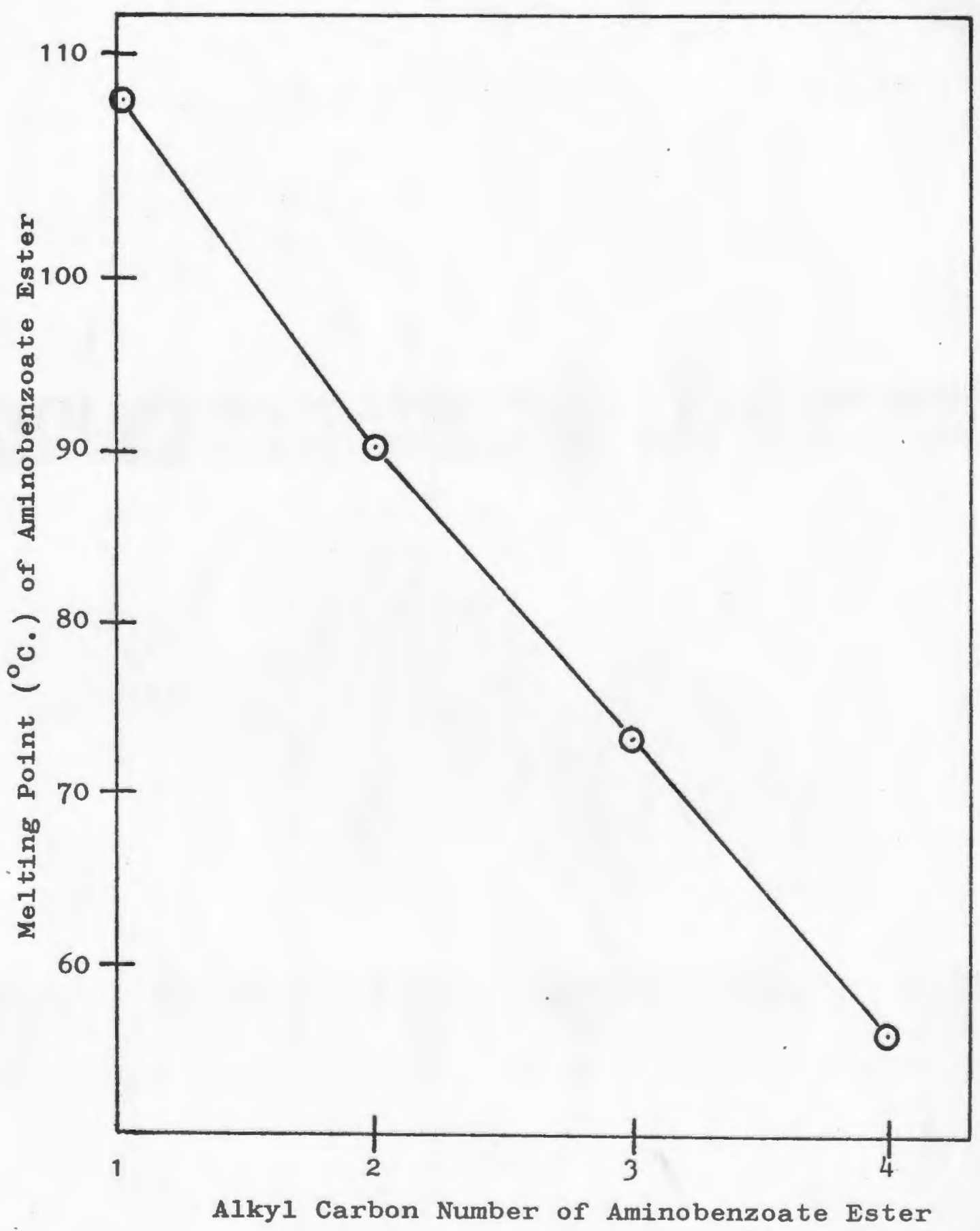

Figure 1. Melting point of Aminobenzoate esters versus the alkyl carbon number. 


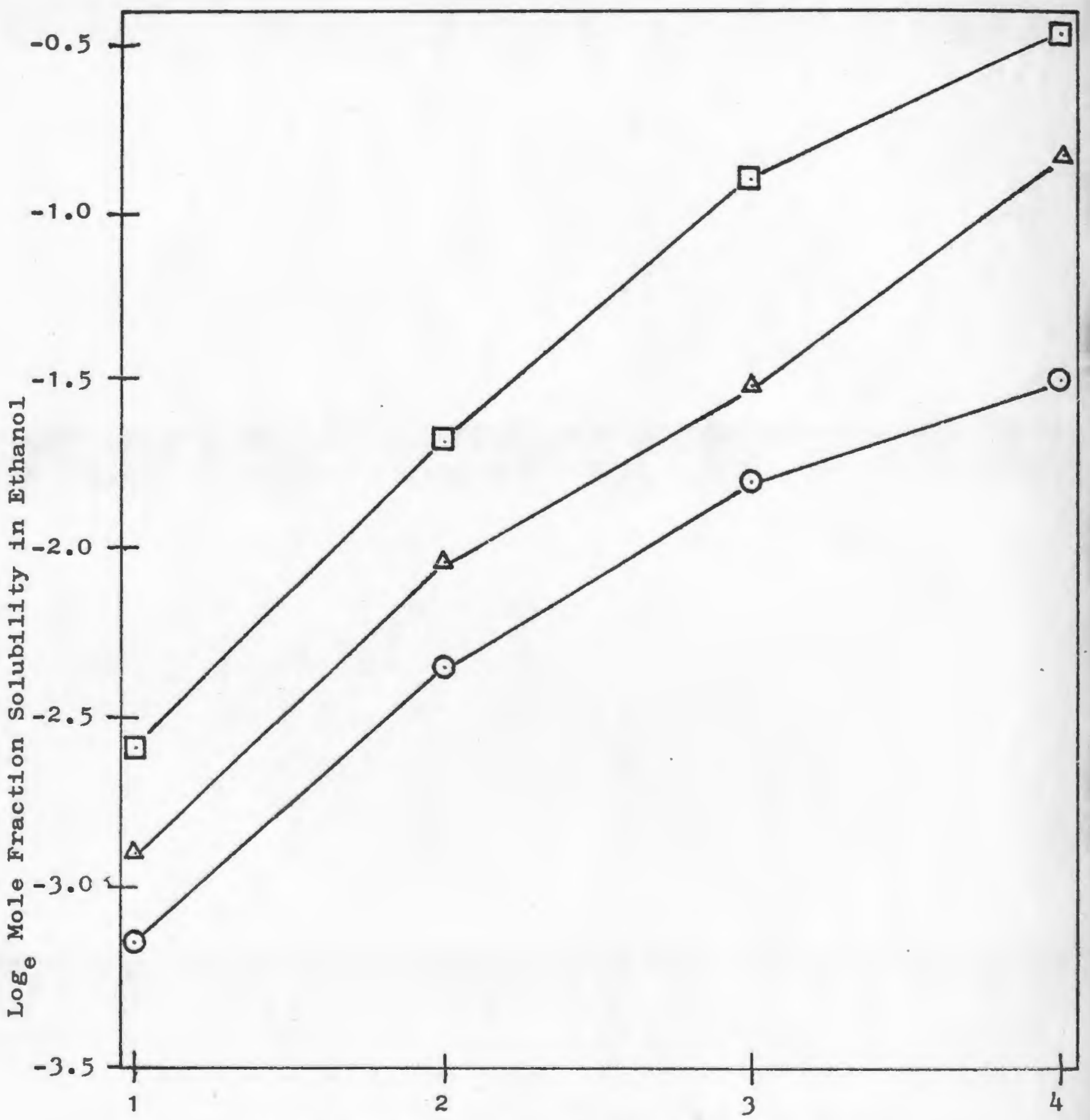

Alkyl Carbon Number of Aminobenzoate Ester

Figure 2. Natural logarithm of mole fraction solubility of the aminobenzoate in ethanol at $\bigcirc 25^{\circ} \mathrm{C} . \mathrm{A} 33^{\circ} \mathrm{C}$.; and $40^{\circ} \mathrm{C}$. versus the alkyl carbon number. 
havior of the solutes in ethanol is similar to the graphs for the other two alcohols, i.e., nearly linear, only one representative graph is presented.

Similarly, plots of $1 n x_{2}$ of the esters dissolved in methanol versus their melting points (Figure 3), illustrates the expected (Equation 3) decreased solubility for each ester as melting point increases. The parallelism observed in Figures 2 and 3 may indicate similar solutesolvent interactions, i.e., a similar mechanism of solubility for the esters in each solvent, within the limited temperature range studied.

The entropies of solution in Table IV have been determined from a least squares analysis (64) of the mole fraction data (Table III). $\mathrm{S}_{\mathrm{S}}{ }^{\mathrm{a}}$ was obtained from the intercepts of $1 n x_{2}$ versus the reciprocal absolute temperature shown graphically in Figure 4 for n-propanol solutions. The Hildebrand entropy of solution, $\mathrm{s}_{s}{ }^{\mathrm{b}}$, was obtained from the slopes of $1 n x_{2}$ versus the natural $\log$ of the absolute temperature, shown graphically in Figure 5 for n-propanol solutions. Since these graphs are similar to the graphs of the other alcoholic solutions, they have been chosen as representative examples of.the solute behavior.

Hildebrand's entropy of solution for the solid solutes, $\mathrm{s}_{\mathrm{s}}{ }^{\mathrm{b}}$, which includes the heat of fusion of the solute (69), have values several entropy units (calories/ mole degree) higher than the corresponding values of entropy 


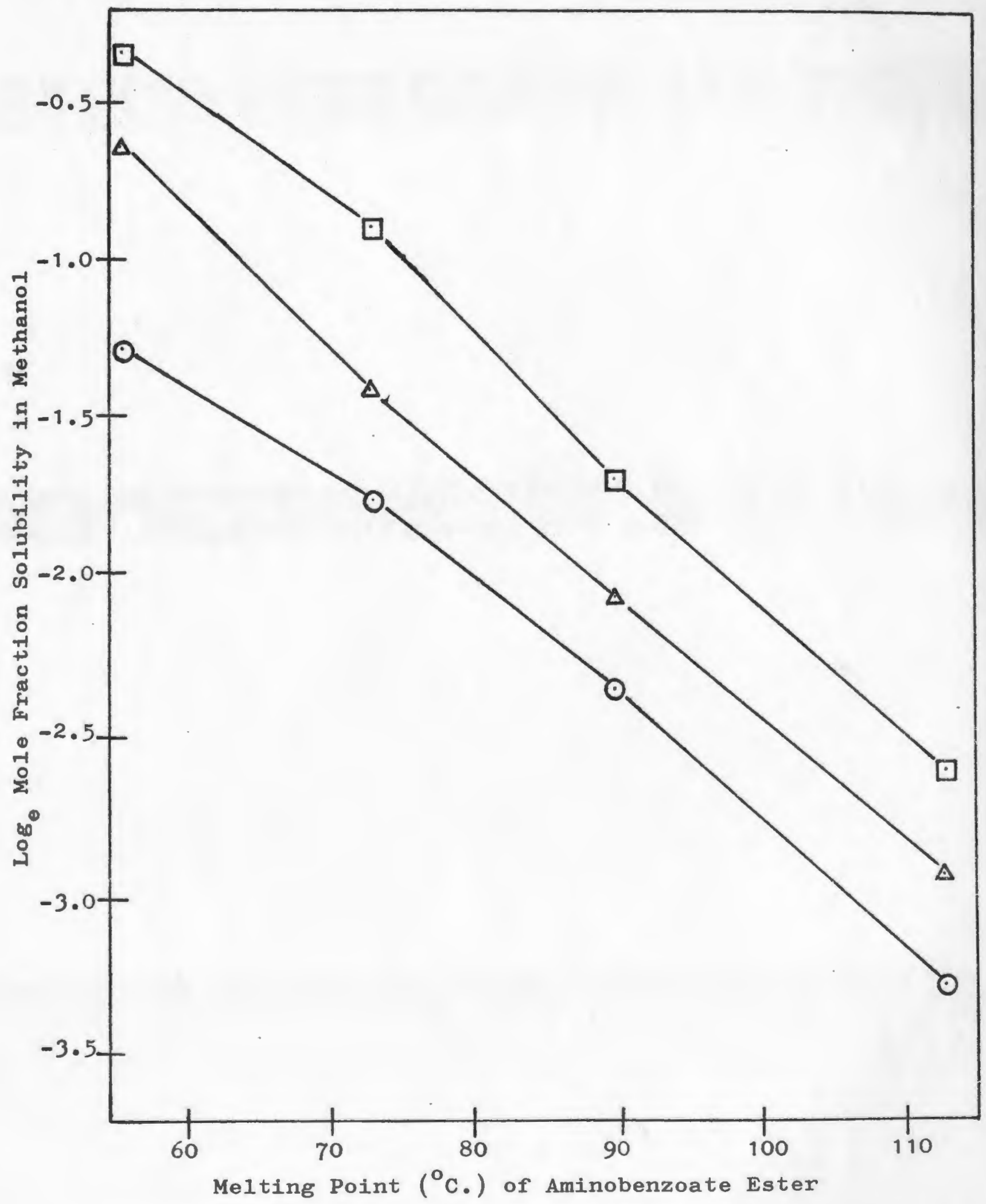

Figure 3. Natural logarithm of mole fraction solubility of the aminobenzoates in methanol at $\odot 25^{\circ} \mathrm{C}$.; $\Delta 33^{\circ} \mathrm{C} . ;$ and $440^{\circ} \mathrm{C}$. versus the melting point. 
TABLE IV

THERMODYNAMIC ENTHALPIES AND ENTROPIES OF SOLUTION

\begin{tabular}{|c|c|c|c|c|c|c|}
\hline $\begin{array}{l}\text { SOLUTE } \\
\text { ESTER }\end{array}$ & SOLVENT & $\begin{array}{l}\Delta \mathrm{H}_{\mathrm{s}} \\
\mathrm{cal} \cdot / \mathrm{mole}\end{array}$ & $\left(\begin{array}{l}\Delta \mathrm{H}_{\mathrm{mix}}^{\mathrm{E}} \\
\mathrm{cal} \cdot \mathrm{mole}\end{array}\right)^{\mathrm{a}}$ & $\underset{\operatorname{cal} . / \operatorname{mole}}{\left(s_{s}^{a}\right)^{b}}$ & $\begin{array}{l}\left(\mathrm{s}_{\mathrm{s}}^{\mathrm{b}}\right)^{\mathrm{c}} \\
\mathrm{cal} \cdot / \mathrm{mole}\end{array}$ & $s_{s}^{a} / s_{s}^{b}$ \\
\hline Methy 1 & $\begin{array}{l}\text { Water } \\
\text { Methanol } \\
\text { Ethanol } \\
\text { n-Propanol }\end{array}$ & $\begin{array}{l}6620 \\
8470 \\
7000 \\
7990\end{array}$ & $\begin{array}{l}1430 \\
3280 \\
1810 \\
2800\end{array}$ & $\begin{array}{r}5.2 \\
21.9 \\
17.2 \\
19.9\end{array}$ & $\begin{array}{l}21 \cdot 7 \\
27 \cdot 7 \\
22.9 \\
26.2\end{array}$ & $\begin{array}{l}4.22 \\
1.27 \\
1.34 \\
1.34\end{array}$ \\
\hline Ethyl & $\begin{array}{l}\text { Water } \\
\text { Methanol } \\
\text { Ethanol } \\
\text { n-Propanol }\end{array}$ & $\begin{array}{l}6260 \\
7990 \\
8900 \\
6710\end{array}$ & $\begin{array}{l}1230 \\
2950 \\
3870 \\
1680\end{array}$ & $\begin{array}{r}2.9 \\
22.1 \\
25 \cdot 1 \\
17 \cdot 5\end{array}$ & $\begin{array}{l}20.5 \\
26.2 \\
29.2 \\
22.1\end{array}$ & $\begin{array}{l}6.98 \\
1.19 \\
1.16 \\
1.26\end{array}$ \\
\hline $\begin{array}{c}\text { Propy } 1 \\
\ddots\end{array}$ & $\begin{array}{l}\text { Water } \\
\text { Methanol } \\
\text { Ethano1 } \\
\text { n-Propanol }\end{array}$ & $\begin{array}{r}4720 \\
10460 \\
10970 \\
8610\end{array}$ & $\begin{array}{l}-282 \\
5460 \\
5960 \\
3600\end{array}$ & $\begin{array}{r}3.4 \\
31 \cdot 5 \\
33 \cdot 1 \\
25 \cdot 5\end{array}$ & $\begin{array}{l}15 \cdot 5 \\
34.3 \\
36.0 \\
28.2\end{array}$ & $\begin{array}{l}4.74 \\
1.09 \\
1.09 \\
1.15\end{array}$ \\
\hline Buty 1 & $\begin{array}{l}\text { Water } \\
\text { Methanol } \\
\text { Ethanol } \\
\text { n-Propanol }\end{array}$ & $\begin{array}{l}11950 \\
11570 \\
12850 \\
10940\end{array}$ & $\begin{array}{l}6650 \\
6270 \\
7550 \\
5640\end{array}$ & $\begin{array}{l}18.0 \\
36.3 \\
40.2 \\
33.9\end{array}$ & $\begin{array}{l}39.2 \\
37.8 \\
42.1 \\
35.9\end{array}$ & $\begin{array}{l}2.17 \\
1.04 \\
1.01 \\
1.06\end{array}$ \\
\hline
\end{tabular}
a. $\Delta \mathrm{H}_{\mathrm{mix}}^{\mathrm{E}}=\Delta \mathrm{H}_{\mathrm{s}}-\Delta \mathrm{H}_{\mathrm{m}}^{\mathrm{F}}$ (Table II)
b. From a least squares analysis: $R$ times intercept of $1 n x_{2}$ versus $1 / T$.
c. From a least squares analysis: R times slope of $1 n x_{2}$ versus $1 n T$. 


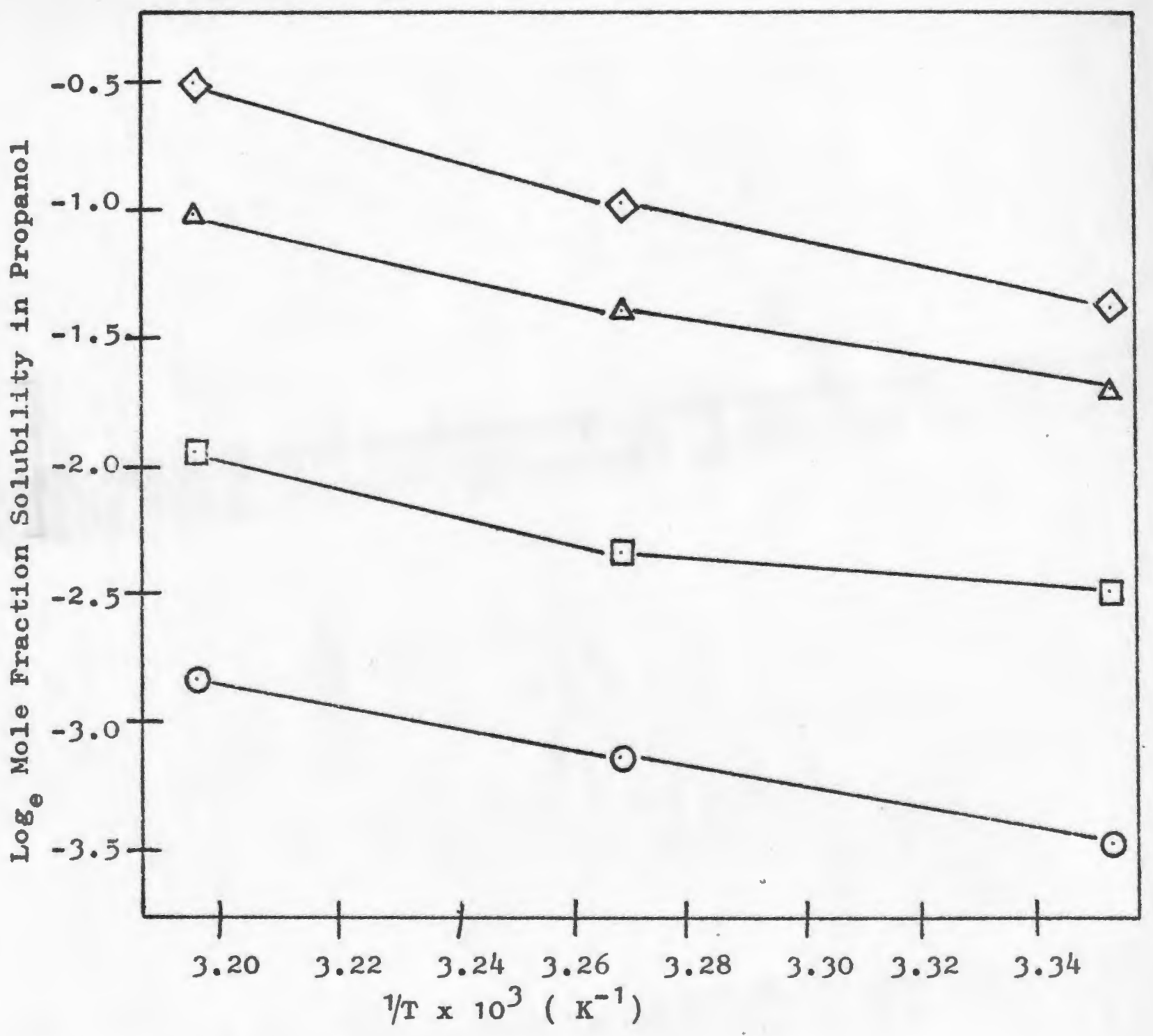

Figure 4. Natural logarithm of mole fraction solubility of methyl, $\mathrm{O}$; ethyl, $\square$; propyl, $\Delta ;$ and buty 1,8 ; aminobenzoate in propanol versus the reciprocal of the absolute temperature. 


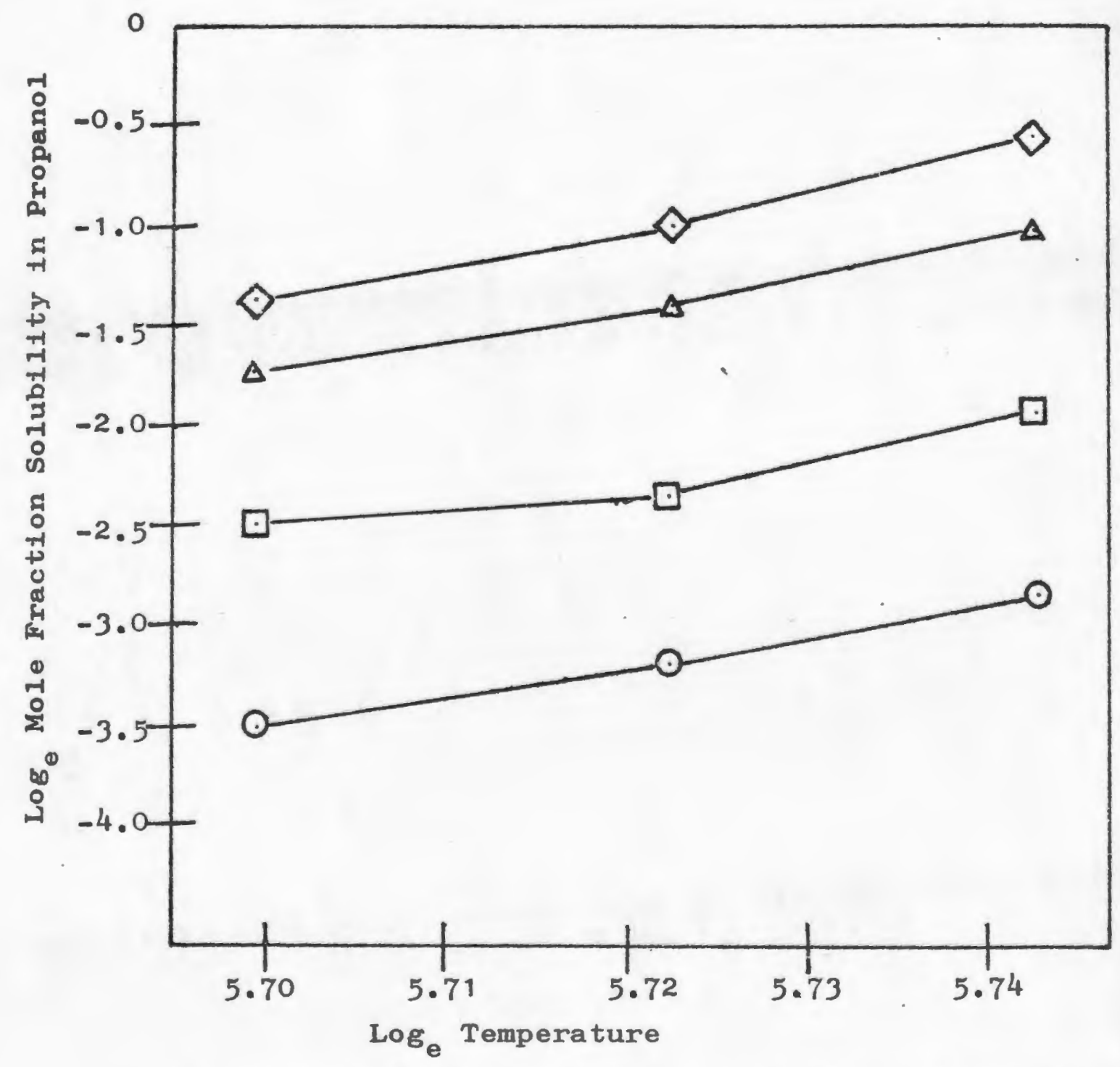

Figure 5. Natural log of the mole fraction solubility of methyl $\odot$; ethyl, $\mathrm{Q}$; propyl, $\Delta ;$ and butyl, $\bigcirc$; aminobenzoate in propanol versus the natural logarithm of the absolute temperature. 
of solution, $s_{s}^{a}$ (Table IV). However, Hildebrand has applied a correction factor to his experimental data from solutions with mole fractions greater than $0.1, i . e .$, good solvents (70). Since this "Henry's law" factor, the change in solute activity per change in solute mole fraction, could not be calculated for the aminobenzoates, all Hildebrand entropy of solution values are uncorrected, and actual values of the entropy of solution, $s_{s} b$, would be less than those given in Table IV.

The diminishing difference between the two values for entropy of solution as the alkyl chain length increases is shown by the decrease in the ratio $s_{s}^{b} / s_{s}^{a}$ in Table IV. Since the two values of the ideal solubilities from Equations 3 and 7 in Table III are reasonably close in value, the ideal values from Equation 3, the conventional method, have been chosen as a basis for comparison in the activity coefficient determinations.

The maximum entropy of solution within a group of solvents denotes the best solvent for that solute, and comparison between groups illustrates the effect of the alcohols upon the solubility of each ester. As the solute alkyl chain length increases, the molecules become less polar and the entropy of solution increases. Although the methyl ester, the most polar of these solutes (17), has a maximum entropy in methanol, the most polar alcohol, all. other esters have their entropic maxima in ethanol, a less polar solvent. 
The heats of solution in Table IV can be compared with the heats of fusion in Table I to show that a positive heat of mixing, $\Delta H_{m i x}$, was generated for all solutions in the alcohols, and that the magnitudes of these heats also increased as the alkyl chain length increased. This excess heat above ideal also showed the most increase in methanol for the methyl ester, and in ethanol for all other esters, 1.e., the same result observed for the entropy of solution data.

Since values for the entropy and heat of solution are determined as averages over a narrow temperature range, they do not reflect the temperature change upon the solubility parameters or the dielectric constants of the solutes. This objection limits the usefulness of separate entropic or enthalpic interpretations of solubility (46).

Solvent polarities can be represented by dielectric constants (Equation 2), and the values for the normal alcohols in Table $V$ show the wide range of polarity of these solvents at the temperatures studied. The nonlinear relationships between the natural log of the solute mole fractions and the dielectric constants of the alcohols at the three temperatures are illustrated in Figures 6,7 , and 8. Although there are obvious polarity changes in the esters with temperature, the lack of apparent solubility maxima indicate that the solubility parameters of the solutes differ from those of the pure solvents. If the solubility 
TABLE V

DIELECTRIC CONSTANTS OF THE ALCOHOLS AT $25^{\circ}, 33^{\circ}$, AND $40^{\circ}$ C. ${ }^{a}$

\begin{tabular}{llll}
\hline ALCOHOL & $25^{\circ} \mathrm{C}$. & $33^{\circ} \mathrm{C}$. & $40^{\circ} \mathrm{C}$. \\
\hline Methanol & 32.63 & 31.09 & 29.80 \\
Ethano1 & 24.30 & 23.12 & 22.14 \\
n-Propano1 & 20.10 & 19.04 & 18.18 \\
\hline
\end{tabular}

a. A. Maryott, and E. Smith, Table of Dielectric Constants of Pure Liquids, National Bureau of Standards, Circular 514, 1957. 


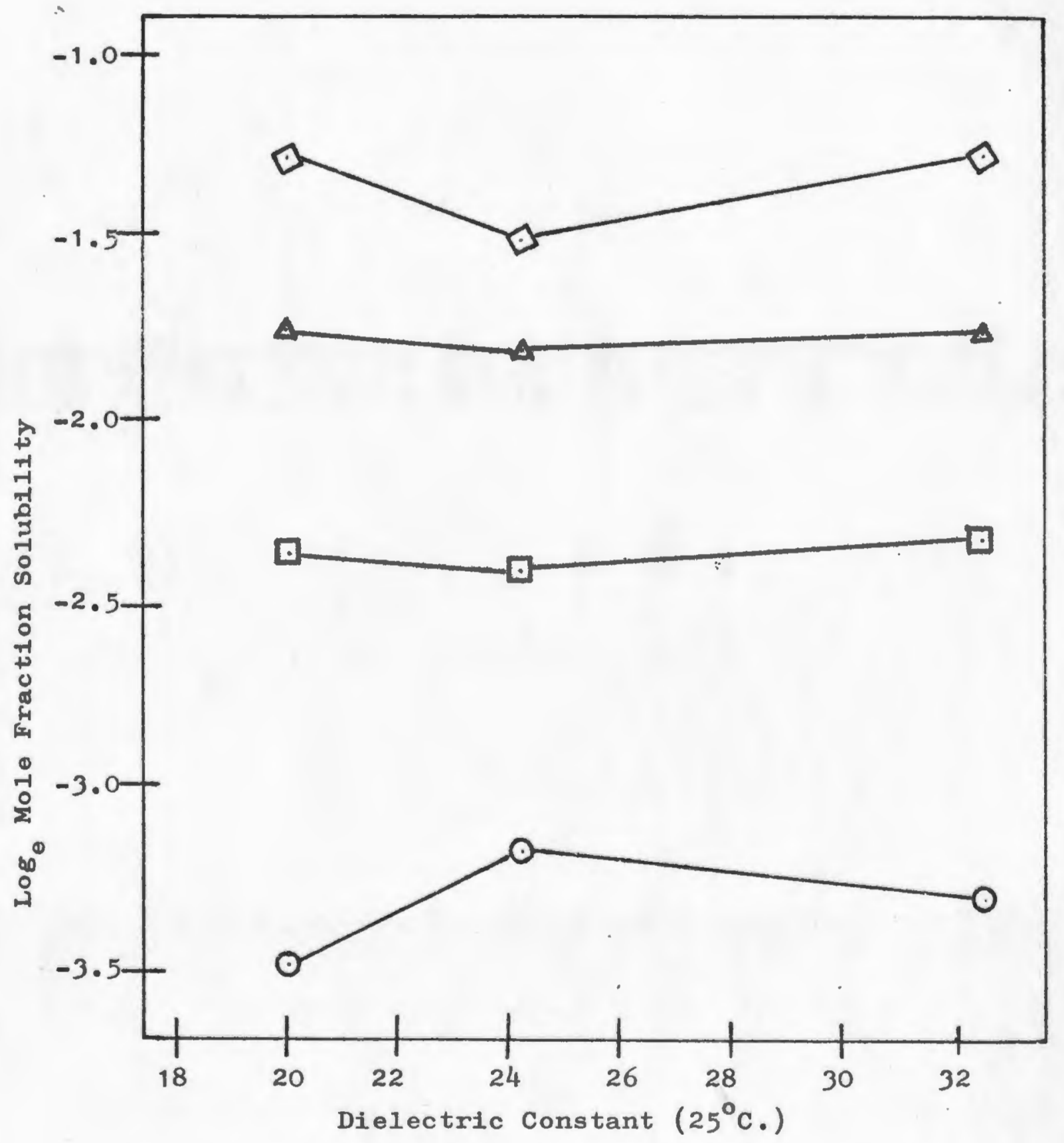

Figure 6. Natural logarithm of mole fraction solubility of methyl, $\mathrm{O}$; ethyl, $\square$; propyl, $\Delta$; and butyl, $\odot$ aminobenzoate versus dielectric constant of the alcohol solvents at $25^{\circ} \mathrm{C}$. 


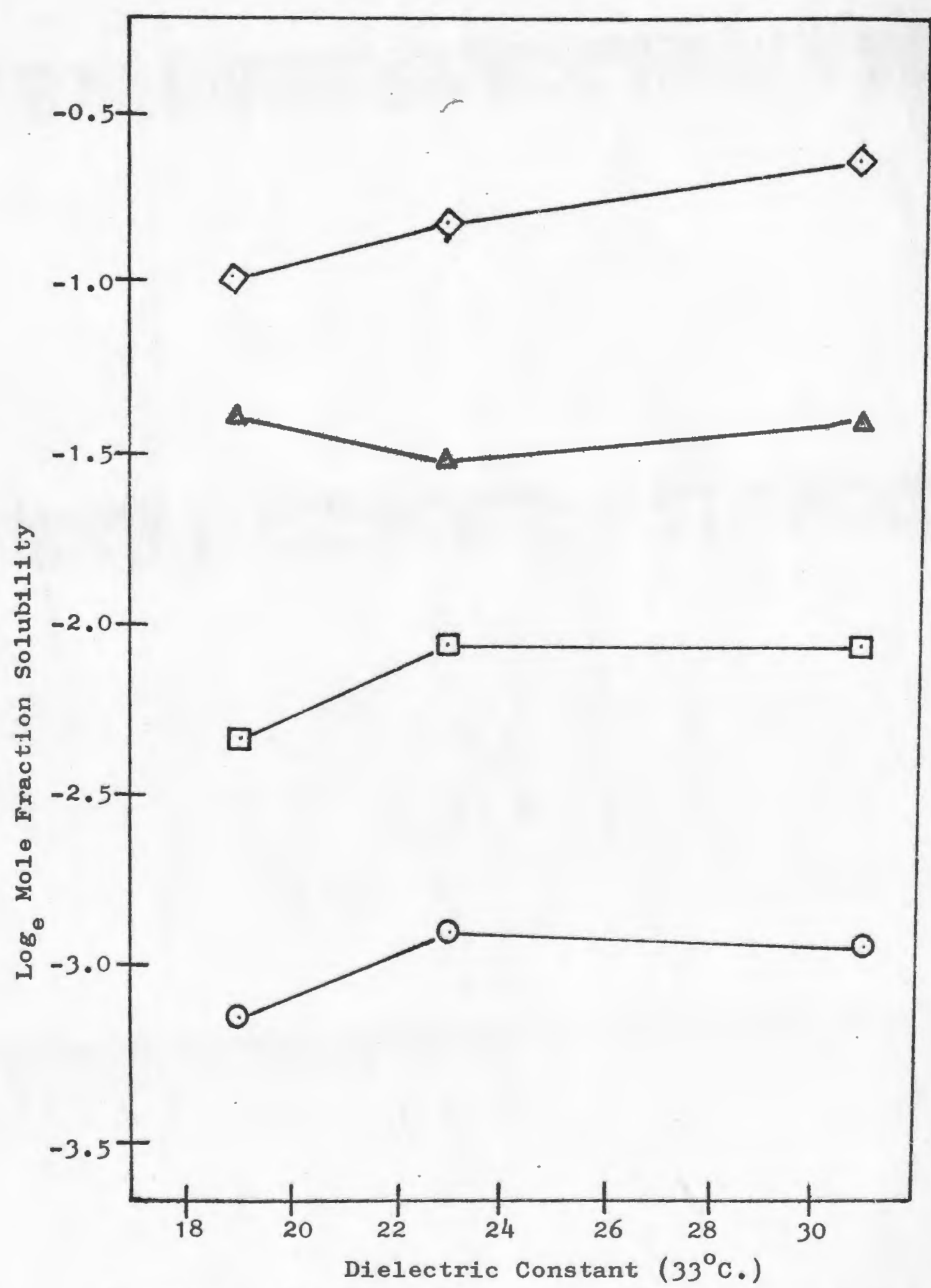

Figure 7. Natural logarithm of mole fraction solubility of methyl, $\odot$; ethyl, $\square$; propyl, $\Delta$; and buty $1, \odot$ aminobenzoate versus

dielectric constant of the normal alcohol solvents at $33^{\circ} \mathrm{C}$. 


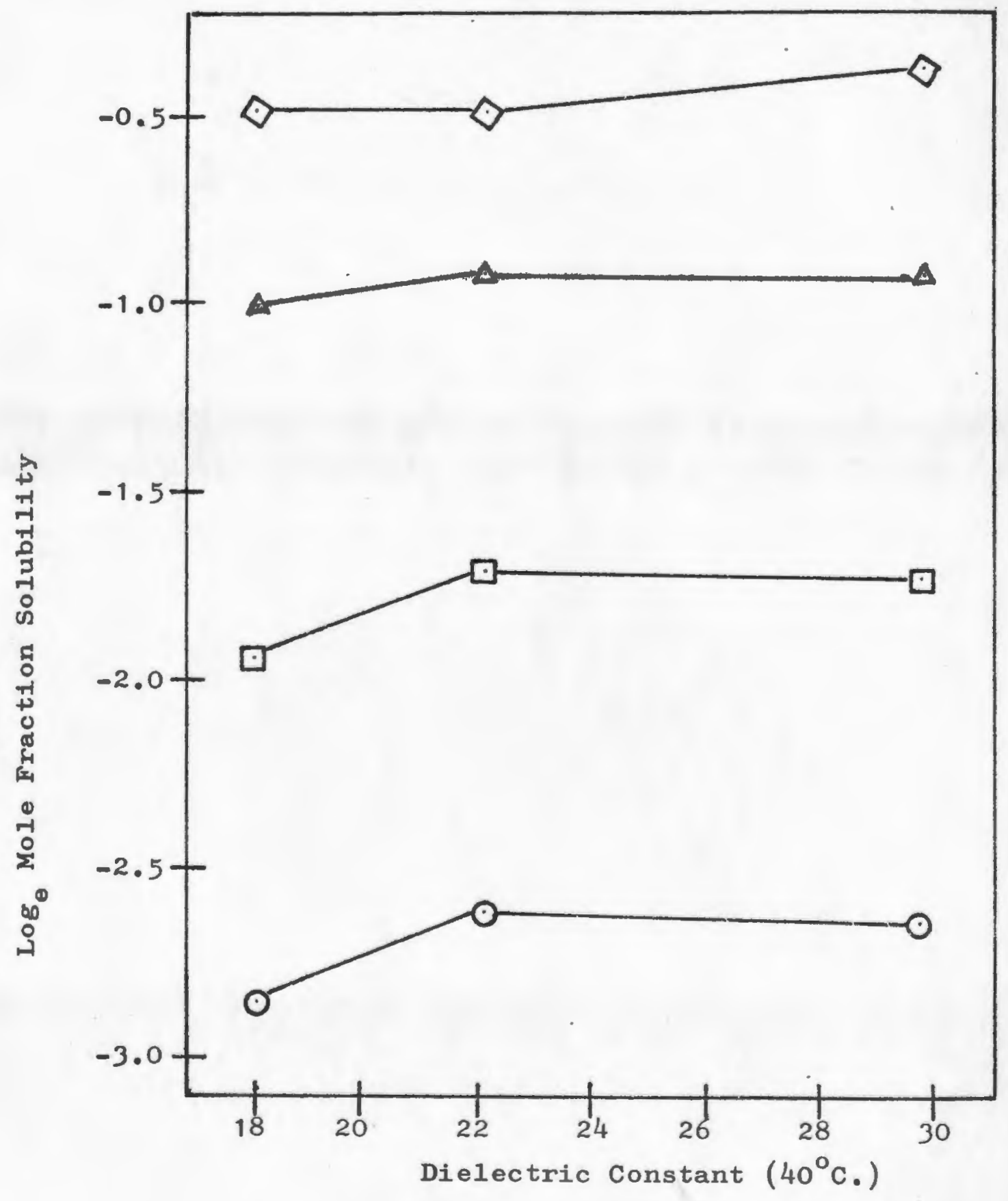

Figure 8. Natural logarithm of mole fraction solubility of methyl, $\odot$; ethyl, $\square$; propyl, $\Delta ;$ and butyi, $\odot$, aminobenzoate versus dielectric constant of the normal alcohol solvent at $40^{\circ} \mathrm{C}$. 
parameter theory is valid for these solutes, it is expected that solute solubility would be greater in a binary solvent blend than in either pure liquid, and should equal the ideal solubility when the dielectric constants of the solute and solvent blend are equal (70), i.e., the dielectric requirement of the solute $(12,13,14,19)$.

The activity coefficients in Table VI are based upon the ideal mole fraction solubilities of Equation 3 and have been used to calculate the partial molal excess free energy of the solutes (Table VII). Since the activity coefficients are high for the methyl ester $(2.82$ to 4.47$)$ and decrease progressively to near unity for the butyl ester $(1.96$ to 0.95$)$, the excess free energies also decrease proportionally. Although free energies near zero were obtained for several butyl solutions at high temperatures, the high entropy of solution values (Table IV) indicate increased molecular disorder (57), and prevent these from being classed as regular solutions.

Solubility of the Aminobenzoates in Water

Although the true structure of water is still unknown, the current theory of its structure $(71,72,73,74)$ emphasizes that hydrogen bonding dominates the properties of water and aqueous solutions. The hydrogen bond is geometrically well defined as the short range interaction between a proton of one molecule and a lone pair of electrons 
TABLE VI

ACTIVITY COEFFICIENTS FOR THE AMINOBENZOATES BASED UPON THE IDEAL SOLUBILITIES FROM EQUATION 3

\begin{tabular}{lccccc}
\hline \multirow{2}{*}{$\begin{array}{c}\text { SOLUTE } \\
\text { ESTER }\end{array}$} & $\begin{array}{c}\text { TEMPERATURE } \\
\text { OC. }\end{array}$ & Water & Methano1 & Ethanol & n-Propanol \\
\cline { 3 - 6 } Methy1 & 25 & 710.5 & 3.7 & 3.3 & 4.5 \\
& 33 & 743.1 & 3.3 & 3.2 & 4.0 \\
& 40 & 628.3 & 2.8 & 2.8 & 3.6 \\
\hline Ethy1 & 25 & 1962.8 & 2.3 & 2.5 & 2.6 \\
& 33 & 1867.3 & 2.2 & 2.2 & 2.9 \\
& 40 & 1775.6 & 1.8 & 1.8 & 2.3 \\
\hline Propyl & 25 & 4844.3 & 1.8 & 1.9 & 1.7 \\
& 33 & 5086.8 & 1.6 & 1.8 & 1.6 \\
& 40 & 4942.8 & 1.2 & 1.2 & 1.3 \\
\hline Butyl & 25 & 28851.3 & 1.6 & 2.0 & 1.7 \\
& 33 & 21869.3 & 1.0 & 1.3 & 1.5 \\
& 40 & 17032.7 & 1.0 & 1.1 & 1.1 \\
\hline
\end{tabular}


TABLE VII

PARTIAL MOLAL EXCESS FREE ENERGIES CALCULATED FROM THE ACTIVITY COEFFICIENTS OF THE AMINOBENZOATES (TABLE VI)

\begin{tabular}{|c|c|c|c|c|c|}
\hline \multirow{2}{*}{$\begin{array}{r}\text { SOLUTE } \\
\text { ESTER }\end{array}$} & \multirow{2}{*}{$\begin{array}{c}\text { TEMPERATURE } \\
{ }^{\circ} \mathrm{C} .\end{array}$} & \multicolumn{4}{|c|}{ SOLVENTS } \\
\hline & & Water & Methano]. & Ethano1 & n-Propano 1 \\
\hline \multirow[t]{3}{*}{ Methy 1} & 25 & -86 & -34 & -30 & -40 \\
\hline & 33 & -112 & -40 & -38 & -48 \\
\hline & 40 & -144 & -44 & -43 & -55 \\
\hline \multirow[t]{3}{*}{ Ethy 1} & 25 & -146 & -33 & -36 & -40 \\
\hline & 33 & -192 & -39 & -38 & -60 \\
\hline & 40 & $-24 \dot{8}$ & -35 & -33 & -55 \\
\hline \multirow[t]{3}{*}{ Propy 1} & 25 & -219 & -30 & -34 & -25 \\
\hline & 33 & -294 & -29 & -39 & -26 \\
\hline & 40 & -388 & -5 & -5 & -12 \\
\hline \multirow[t]{3}{*}{ Buty 1} & 25 & -336 & -30 & -58 & -41 \\
\hline & 33 & -476 & -1 & -16 & -38 \\
\hline & 40 & -678 & -2 & -2 & -3 \\
\hline
\end{tabular}


on the oxygen of another (70). This extensive three dimensional, hydrogen-bonded network is short lived and consists of tetrahedrally coordinated molecules similar in structure to the ice I model or clathrate "ices" (72), where each molecule is joined by a hydrogen bond to its four nearest neighbors.

Nemethy and Scherega (73) state that the interaction of nonpolar groups with water is unfavorable in terms of van der Waais forces and hydrogen bonding and that nonpolar groups may change the structure of water surrounding these groups. There is a tendency for nonpolar groups, such as the ester side chains of the aminobenzoates, to interact with each other as much as possible rather than remain surrounded by water. This interaction is termed hydrophobic bonding and is presumed to account for an increase in free energy of mixing. However, the rather low solubility of nonpolar compounds in water is the result. of unfavorable thermodynamics of solution, i.e., a large decrease in the entropy of solution over ideal (excess entropy), attributed to increased ordering of water molecules through hydrogen bonding $(73,74)$.

Kauzmann (74) has calculated large negative entropies of solution for hydrocarbons dissolved in water, but he indicates that aromatic compounds should have less negative or even slightly positive entropies. The characterization of the hydrophobic bond still remains unclear, since mole- 
cules may be governed by the interfacial interactions between the nonpolar portion of the molecule and the high surface energy of water (75). This type of interaction would result in positive enthalpies and entropies of solution (74).

In Table IV the mole fraction solubilities of the alkyl p-aminobenzoates in water at the three temperatures are significantly lower than the corresponding solubilities in the alcohols. A plot of $1 \mathrm{n} x_{2}$ of the esters against the alkyl carbon number (Figure 9) shows a somewhat linear relationship for the methyl, ethyl, and propyl esters; however, the butyl ester does not conform to the linearity of the first three esters. The solubility of the esters in water differs in another way from that observed in the alcohols, i.e., the most polar solute, methyl p-aminobenzoate, has the highest solubility in water, and the butyl ester, the least polar, has the lowest solubility in water.

The natural logarithmic solubilities of the aminobenzoates are linear with respect to both reciprocal temperature $(1 / T)$ in Figure 10, and the natural $\log$ of $T$ ( $1 \mathrm{n} \mathrm{T}$ ) in Figure 11. The enthalpies and entropies obtained from the least squares analysis have been listed in Table IV. The fact that the propyl ester was the only solute that had a negative enthalpy of mixing in water, perhaps indicates a greater hydrogen bonding of the water around the propyl than around the other esters. 


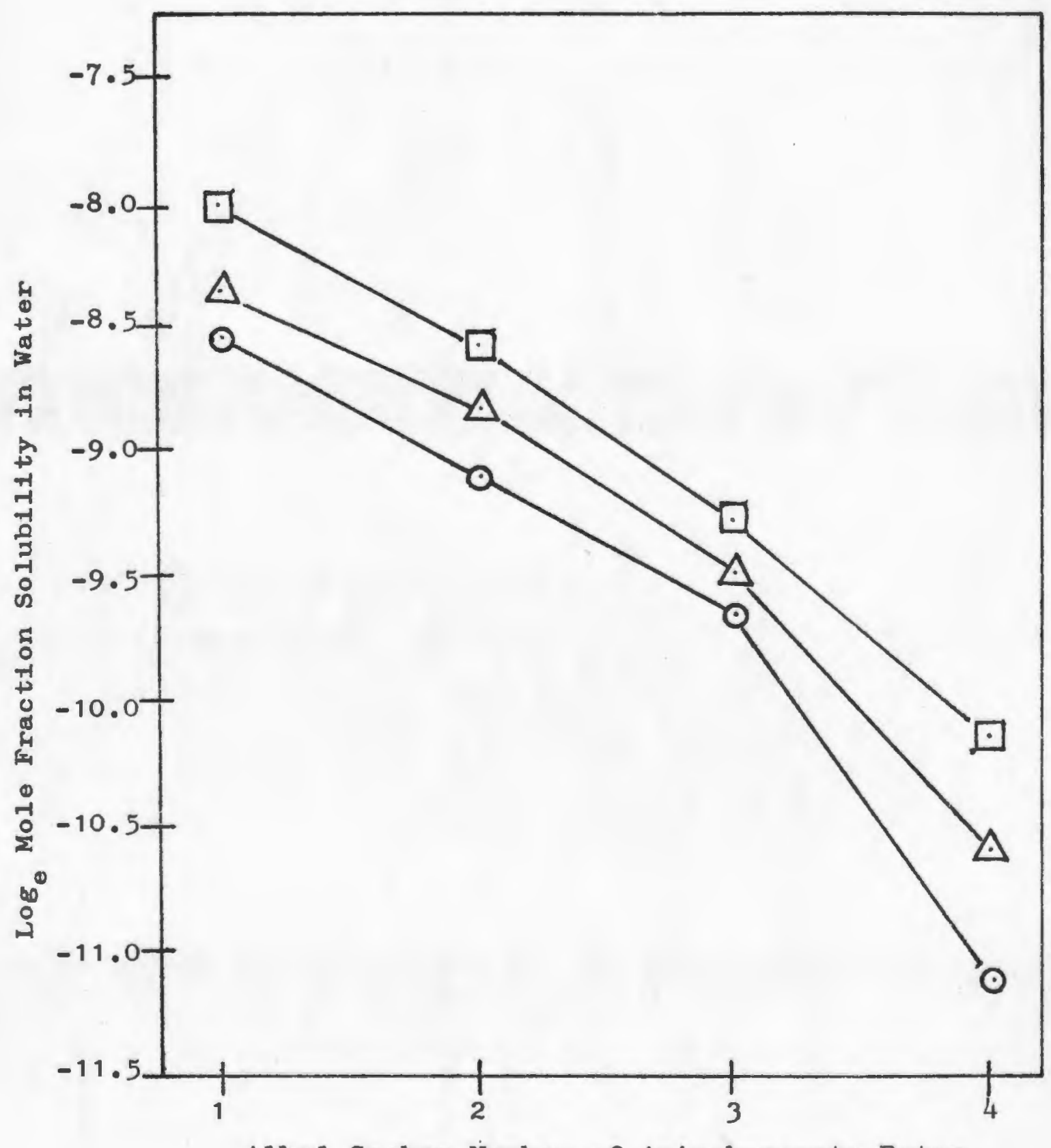

Alky1 Carbon Number of Aminobenzoate Ester

Figure 9. Natural logarithm of mole fraction solubility of the aminobenzoates in water at $25^{\circ} \mathrm{C} ., \odot ; 33^{\circ} \mathrm{C}, \Delta ;$ and $40^{\circ} \mathrm{C} ., \square$; versus the alkyl carbon number. 


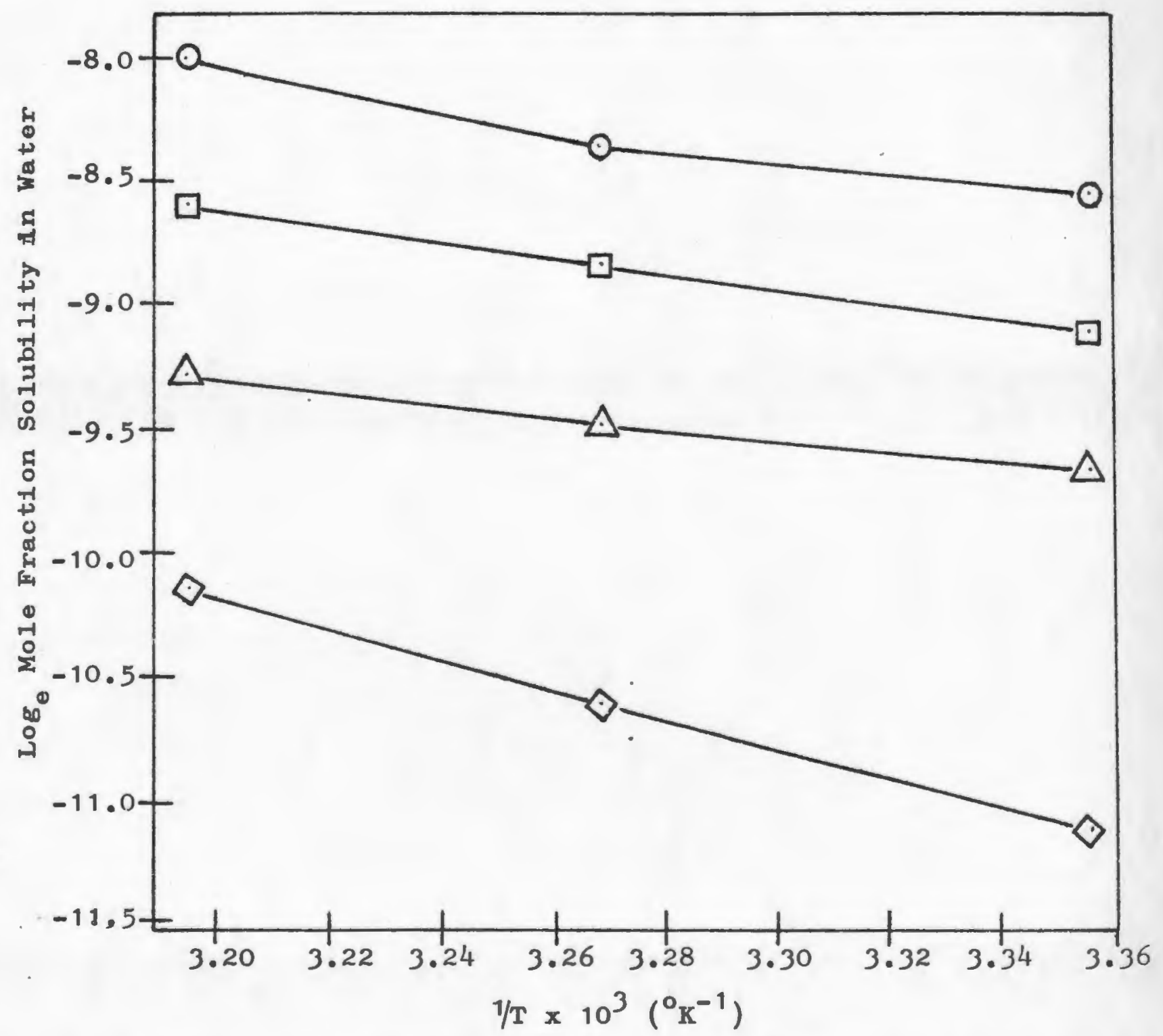

Figure 10. Natural logarithm of mole fraction solubility of methy $1, \Theta$; ethy $1, \nabla$; propyl, $\Delta ;$ and buty $1, \odot$, aminobenzoate in water versus the reciprocal of the absolute temperature. 


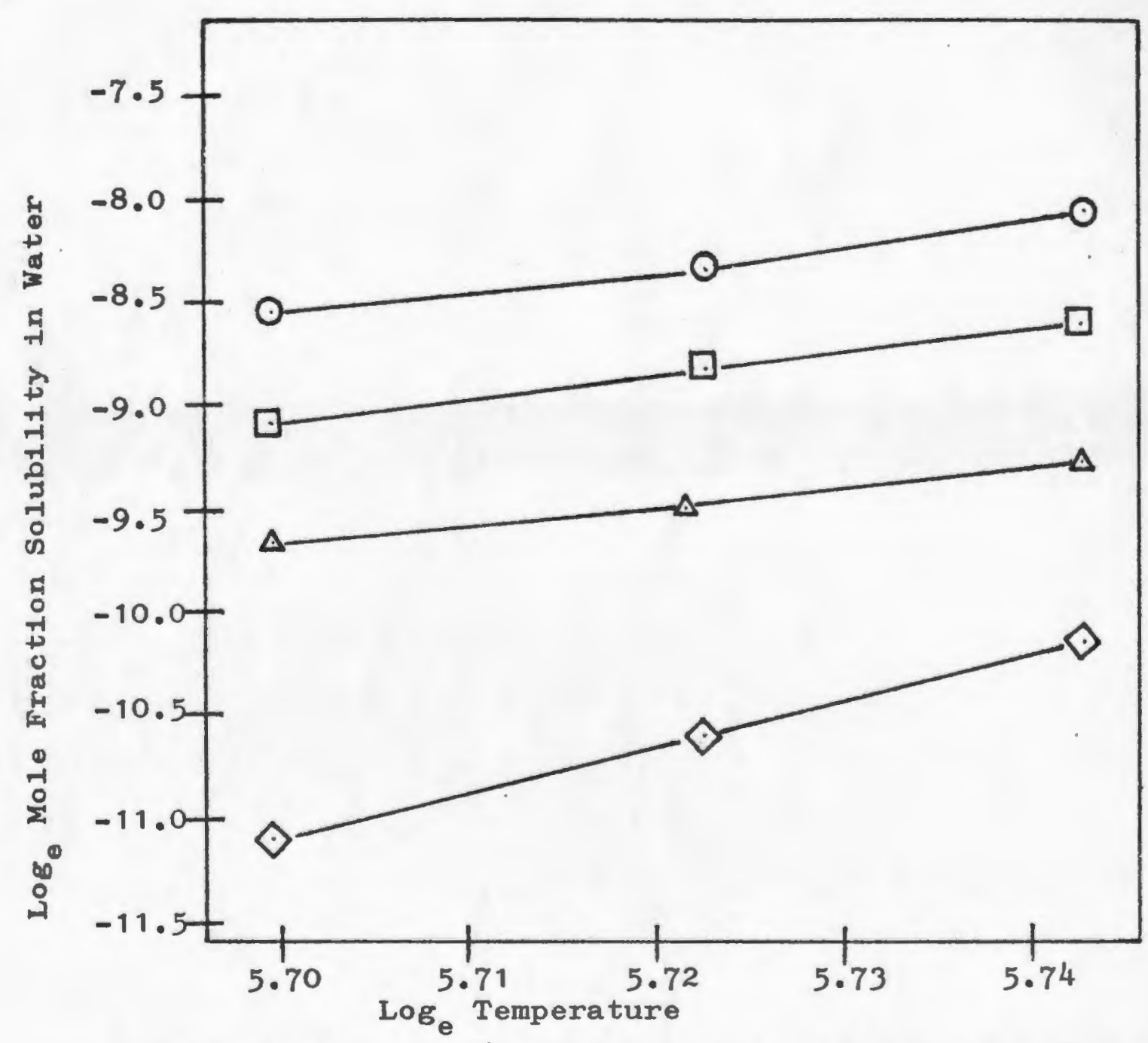

Figure 11. Natural logarithm of mole fraction solubility of methyl, $\odot$; ethy $1, \square$; propy $1, \Delta$; and buty $1, \odot$, aminobenzoate in water versus the natural logarithm of the absolute temperature. 
Because the solubility of the esters in water is so low, the activities in Table VI and the partial excess free energies in Table VII differ greatly from those of the alcohols. The entropy of solution values, $s_{s}{ }^{a}$, for the esters are lower than their entropy of fusion values (Table I), a result expected for aromatic molecules according to the hydrophobic bond theory (74). However, the values for the Hildebrand entropy of solution, $s_{s} b$, which include the heat capacity of the solute, are unexpectedly higher than their corresponding entropy of fusion values. This may indicate a change in solute heat capacity for such hydrogen bonded and highly nonideal systems (76).

Quantitative disagreement between ideal and actual mole fraction solubilities (Table III) reflected by the large activity coefficients in Tabie VI indicate that the Hildebrand and Scott solubility parameter theory does not fully describe the solute-solvent interactions of these highly nonideal systems (77). Since water and the alcohols are not spherical molecules (71), their large dipole moments account for large dipole orientation forces, w (78). The internal pressure or the cohesive energy density of Equation 1 can be redefined as the sum of the solubility parameter and this orientation force, i.e. (78).

$$
\left(\mathrm{E}^{\mathrm{vap}} / \mathrm{v}\right)^{1 / 2}=\alpha^{2}+w^{2}
$$

Hildebrand (78) claims that "for a solution of one polar and one nonpolar component, ideal solutions are impossible, 
even if the solubility parameters are equal," and the heat of mixing for such solutions is always positive and greater than that calculated from the solubility parameter theory.

The limitations and frustrations of solubility investigations has been succinctly summarized by Hildebrand:

We seek the best or sometimes the poorest solvent for a certain solute. We seldom want to know a solubility to, say, 1 percent and, indeed, we seldom control temperature or purity to a corresponding degree. If we do need a solubility to that accuracy we must rely upon measurement, better measurement, indeed, than many in the literature. All theory can do for us in that case is to select, out of the scores of solvents upon our shelves, the few likely to serve our purpose. (79) 


\section{SUMMARY}

1. The physical parameters of melting point and heat of fusion were determined for the first four homologous normal alkyl p-aminobenzoates. The melting point temperature decreases almost linearly with increasing alkyl chain length. However, the heats of fusion are not linearly related to the alkyl chain length.

2. The solubilities of these four alkyl p-aminobenzoates dissolved in three normal alcohols and water were determined and calculated as mole fractions. From these data the order of solubility of the methyl through butyl esters increases in alcoholic solutions, and decreases in aqueous solutions. There is a direct relationship between the $\log$ mole fraction solubility and the alkyl carbon number of the esters.

3. The magnitudes of the solubility of these esters dissolved in the normal alcohols and water increased with increased temperature, and is indicative of an endothermic dissolution process. The conventional relationship between the natural log mole fraction data and the reciprocal temperature was linear for all solutions and produced values for the enthalpy and entropy of solution. The Hildebrand entropy of solution values were obtained from the linear relationship 
between the natural log mole fraction solubility and the $\log$ of the absolute temperature. The Hildebrand entropy values include the heat capacity of the solute.

4. Thermodynamic data for the aminobenzoates dissolved in the normal alcohols indicate increased entropy of solution as the alkyl chain length increases. There was no significant difference between the conventional entropy of solution values and the Hildebrand entropy of solution values. Although the butyl ester was highly soluble in the alcohols, the high entropy of solution values indicate a random array of molecules.

5. The entropy of solution values for the solubility of the aminobenzoates in water do not appear to be directly related to the alkyl chain length. Furthermore, the Hildebrand entropy of solution values are much higher than those calculated by the conventional method, a difference which may be attributed to an increase in heat capacity of the solutes in water. 6. The dielectric constants of the solvents represent their wide range of polarities, however, there is no direct relationship between solubility of the esters and the carbon number of the alcohols. Because pure solvents rather than solvent blends were used, the Hildebrand solubility parameter theory is apparently not valid for such highly nonideal solutions. 
7. From the heat of fusion and the melting point data determined for these solutes, their ideal mole fraction solubilities were calculated. Activity coefficients of the solutes compare ideal to actual solubilities and were used to calculate partial molal excess free energies. These free energies were near zero in some cases, but the high entropy of solution values for these solutions do not indicate regular solutions.

8. Because of their low solubility in water, the aminobenzoates have very high activity coefficients. The Hildebrand solubility parameter theory has been modified to include a dipole orientation force to explain this highly nonideal behavior. 
VIII: REFERENCES

1. T. Higuchi, "Solubility" in R. Layman, Pharmaceutical Compounding and Dispensing, Lippincott Company, Philadelphia, 1949, Chapter 7.

2. J. C. Krantz, and C. J. Carr, The Pharmacologic Principles of Medical Practice, 6th ed., Williams and Wilkins Company, Baltimore, 1965, Chapter 17.

3. F. H. Meyers, E. Jawetz, and A. Goldfien, Review of Medical Pharmacology, 2nd. ed., Lange Medical Publications, Los Altos, California, 1970, Chapter 22.

4. C. 0. Wilson, 0. Gisvold, and R. F. Doerge, Textbook of Organic Medicinal and Pharmaceutical Chemistry, 5th ed., J. B. Lippincott Company, Philadelphia, 1966, Chapter 2.

5. H. O. Evans, Austral. J. Pharm., 49, s75 (1968).

6. L. S. Goodman, and A. Gilman, The Pharmacological Basis of Therapeutics, 4th. ed., Macmillan Company, New York, 1970, Chapter 20.

7. R. Adams, E. K. Pidea 1, W. B. Burnett, R. L. Jenkins, and E. F. Droger, J. Amer. Chem. Soc., 48, 1758 (1926).

8. M. Sax, and J. Pletcher, Science, 166, 1546 (1969).

9. F. A. Restaine, and A. N. Martin, J. Pharm. Sci., 53, 636 (1964).

10. A. N. Paruta, J. Pharm. Sci., 58, 216 (1969).

11. J. H. Hildebrand, and R. L. Scott, The Solubility of Nonelectrolytes, 3rd ed., Reinhold Publishing Corp., New York, 1949.

12. A. N. Paruta, B. J. Sciarrone, and N. G. Lordi, J. Pharm. Sci., 53, 1349 (1964).

13. M. J. Chertkoff, and A. N. Martin, J. Amer. Pharm. Assoc., Sci. Ed., 49, 444 (1960).

14. W. G. Gorman, and G. D. Ha11, J. Pharm. Sci., 53, 1017 $(1964)$. 
15. J. H. Hildebrand, J. M. Prausnitz, and R. L. Scott, Regular and Related Solutions, Van Nostrand Reinhold Company, New York, 1970.

16. J. Ferguson, J. Proc. Roy. Soc. (Series B), 127, 397 (1939).

17. S. H. Yalkowsky, G. L. Flynn, and T. G. Slunick, J. Pharm. Sci., 61, 853 (1972).

18. A. Martin, Physical Pharmacy, Lea and Febiger, Philadelphia, 1960, p. 359.

19. A. N. Paruta, Amer. Jour. Pharm., 138, 137 (1966).

20. J. H. Hildebrand, Science, 150, 441 (1965).

21. G. N. Lewis, and M. Randa11, Thermodynamics, McGrawHill Book Company, New York, 1923, p. 221.

22. B. H. Mahan, Elementary Chemical Thermodynamics, W. A. Benjamin, New York, 1963, Chapter 4.

23. D. Dreisbach, Liquids and Solutions, Houghton Mifflin Company, Boston, 1966, Chapter 12.

24. R. E. Lindstrom, J. Pharm. Sci., 59, 1965 (1970).

25. R. Orwell, P. J. Flory, and A. Vrig, J. Amer. Chem. Soc., 8ㄷ, 3507 (1964).

26. H. Fung, and T. Higuchi, J. Pharm. Sci., 60, 1782 (1971).

27. J. W. Mauger, A. N. Paruta, and R. J. Gerraughty, J. Pharm. Sci., 61, 94 (1972).

28. L. K. Nash, Elements of Chemical Thermodynamics, Addison, Wesley, Reading, Mass:, 1970, Chapter 4.

29. J. H. Hildebrand, and R. L. Scott, op. cit., p. 47.

30. J. H. Hildebrand, and R. L. Scott, op. cit., p. 28.

31. J. H. Hildebrand, and R. L. Scott, Regular Solutions, Prentice Hall, Inc., Englewood Cliffs, N. J., 1962, p. 132 .

32. J. H. Hildebrand, and R. L. Scott,op cit, p. 27.

33. J. H. Hildebrand, and R. L. Scott, ibid., p. 13. 
34. J. H. Hildebrand, and R. L. Scott, 吕1d., p. 270.

35. J. H. Hildebrand, and R. L. Scott, Regular Solutions, p. 20 .

36. J. H. Hildebrand, J. M. Prausnitz, and R. L. Scott, op. c1t., p. 144 .

37. J. H. Hildebrand, J. Amer. Chem, Soc., 21, 66 (1929).

38. P. A. Rock, Chemical Thermodynamics, Principles and Applications, MacMillan Company, London, 1969, p. 263.

39. A. Martin, ㅇp. c1t., p. 149.

40. A. Martin, ibid., p. 348.

41. J. H. Fildebrand, and R. L. Scott, 으. 1ㅗ., p. 119.

42. J. H. Hildebrand, and R. L. Scott, ibid., p. 46.

43. J. H. Fildebrand, and R. L. Scott, 1bid., p. 138.

44. G. N. Lewis, and M. Randa11, op. cit., p. 158.

45. J. H. Hildebrand, and R. L. Scott, 오. c1t., p. 44.

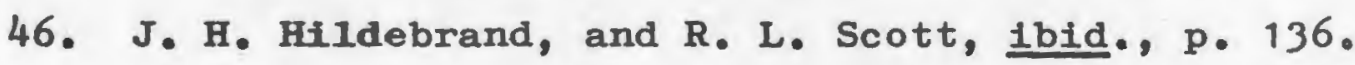

47. J. H. Hildebrand, J. M. Prausnttz, and R. L. Scott, op. cit., p. 17.

48. P. A. Rock, op. c1t., p. 265.

49. J. H. Hildebrand, and R. L. Scott, op. c1t., p. 29.

50. G. Scatchard, Chem, Revs., 44, 7 (1949).

51. J. H. Hildebrand, and R. L. Scott, op. cit., p. 5.

52. J. H. Hildebrand, and R. L. Scott, 1bid., p. 14.

53. A. Martin, op. c1t., p. 358.

54. J. H. Hildebrand, and R. L. Scott, op. cit., p. 271.

55. J. H. HAldebrand, and R. L. Scott, 吕., p. 129.

56. M. B. Rodell, W. L. Guess, and J. Autian, I. Pharm. Sci., 55, 1429 (1966). 
57. J. H. Hildebrand, Science in the Making, Columbia University Press, 1957, p. 78 .

58. J. H. Hildebrand, and R. L. Scott, op. cit., p. 218.

59. J. K. Guillory, J. Pharm. Sci., 56, 72 (1967).

60. R. Reubke, and J.A. Mollica, J. Pharm. Sci., 56, 822 (1967).

61. S. S. Yang, and J. K. Guillory, J. Pharm. Sci., 61, 26 (1972).

62. R. C. Weast, Handbook of Chemistry and Physics, 51st. ed., Chemical Rubber Company, Cleveland, 1970.

63. A. Martin, Physical Pharmacy, Lea and Feabiger, Philadelphia, 1960, p. 341 .

64. IBM, CALL/360 Statistical Package (STATPACK), Version 2, International Business Machines, White Plains, N. Y., 1967 .

65. A. Martin, op. cit., p. 132.

66. A. E. Lewis, Biostatistics, Reinhold Publishing Company, New York, 1966, p. 76.

67. A. Martin, op. cit., p. 132.

68. E. G. C. Clarke, Isolation and Identification of Drugs, The Pharmaceutical Press, London, 1969.

69. J. H. Hildebrand, J. M. Prausnitz, and R. L. Scott, op. cit., p. 80 .

70. J. H. Hildebrand, J. M. Prausnitz, and R. L. Scott, op. cit., p. 76 .

71. H. S. Frank, Science, 169, 1635 (1970).

72. A. H. Narten, and H. A. Levy, Science, 165, 447 (1969).

73. G. Nemethy, and H. A. Scheraga, J. Phys. Chem,, 66, $1773(1962)$.

74. W. Kauzmann, Advan. Protein Chem, 14, 1 (1959).

75. H. Kristiansen, M. Nakano, N. Nakano, and T. Higuchi, J. Pharm. Sci., 59, 1103 (1970).

76. P. A. Rock, op. cit., p. 267. 
77. J. H. Hildebrand, J. M. Prausnitz, and R. L. Scott, ㅇp. cit., p. 150.

78. J. H. Hildebrand, and R. L. Scott, op. cit., p. 168.

79. J. H. Hildebrand, Chem. Revs., 44, 37 (1949). 